\title{
Technological Approaches for Improving Vaccination Compliance and Coverage
}

\author{
Céline Lemoine ${ }^{1,2,+}$, Aneesh Thakur ${ }^{3,+}{ }^{+}$, Danina Krajišnik ${ }^{4}$, Romain Guyon ${ }^{5}(\mathbb{D}$,

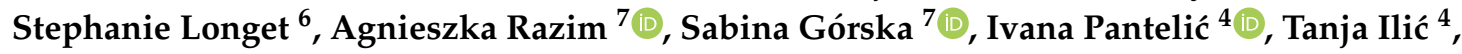 \\ Ines Nikolić ${ }^{4}$, Ed C. Lavelle ${ }^{8} \mathbb{D}$, Andrzej Gamian ${ }^{9}{ }^{\mathbb{D}}$, Snežana Savić ${ }^{4}$ and Anita Milicic ${ }^{5, *}$ \\ 1 Institute of Pharmaceutical Sciences of Western Switzerland, University of Geneva, Rue Michel-Servet 1, \\ 1221 Geneva, Switzerland; celine.lemoine@unige.ch \\ 2 Vaccine Formulation Institute, Chemin des Aulx 14, 1228 Plan-les-Ouates, Switzerland \\ 3 Department of Pharmacy, Faculty of Health and Medical Sciences, University of Copenhagen, \\ Universitetsparken 2, 2100 Copenhagen Ø, Denmark; aneesh.thakur@sund.ku.dk \\ 4 Department of Pharmaceutical Technology and Cosmetology, University of Belgrade-Faculty of Pharmacy, \\ Vojvode Stepe 450, 11221 Belgrade, Serbia; danina.krajisnik@pharmacy.bg.ac.rs (D.K.); \\ ivana.pantelic@pharmacy.bg.ac.rs (I.P.); tanja.ilic@pharmacy.bg.ac.rs (T.I.); \\ ines.nikolic@pharmacy.bg.ac.rs (I.N.); snezana.savic@pharmacy.bg.ac.rs (S.S.) \\ 5 The Jenner Institute, Nuffield Department of Medicine, University of Oxford, \\ Old Road Campus Research Building, Roosevelt Drive, Oxford OX3 7DQ, UK; romain.guyon@ndm.ox.ac.uk \\ 6 Virology \& Pathogenesis Group, Public Health England, Manor Farm Road, Porton Down, \\ Salisbury SP4 0JG, UK; stephanie.longet@phe.gov.uk \\ 7 Department of Microbiology, Hirszfeld Institute of Immunology and Experimental Therapy, \\ Polish Academy of Sciences, ul. Rudolfa Weigla 12, 53-114 Wroclaw, Poland; \\ agnieszka.razim@hirszfeld.pl (A.R.); sabina.gorska@hirszfeld.pl (S.G.) \\ 8 The Adjuvant Research Group, School of Biochemistry and Immunology, Trinity Biomedical Sciences \\ Institute, Trinity College Dublin, DO2R590 Dublin, Ireland; lavellee@tcd.ie \\ 9 Department of Immunology of Infectious Diseases, Hirszfeld Institute of Immunology and Experimental \\ Therapy, Polish Academy of Sciences, ul. Rudolfa Weigla 12, 53-114 Wroclaw, Poland; \\ andrzej.gamian@hirszfeld.pl \\ * Correspondence: anita.milicic@ndm.ox.ac.uk \\ + These authors contributed equally.
}

Received: 22 May 2020; Accepted: 14 June 2020; Published: 16 June 2020

check for updates

\begin{abstract}
Vaccination has been well recognised as a critically important tool in preventing infectious disease, yet incomplete immunisation coverage remains a major obstacle to achieving disease control and eradication. As medical products for global access, vaccines need to be safe, effective and inexpensive. In line with these goals, continuous improvements of vaccine delivery strategies are necessary to achieve the full potential of immunisation. Novel technologies related to vaccine delivery and route of administration, use of advanced adjuvants and controlled antigen release (single-dose immunisation) approaches are expected to contribute to improved coverage and patient compliance. This review discusses the application of micro- and nano-technologies in the alternative routes of vaccine administration (mucosal and cutaneous vaccination), oral vaccine delivery as well as vaccine encapsulation with the aim of controlled antigen release for single-dose vaccination.
\end{abstract}

Keywords: vaccine delivery; compliance; microfluidics; mucosal vaccination; cutaneous vaccination; adjuvants 


\section{Introduction}

Estimated global immunisation coverage varies per country and per vaccine, with some vaccines such as pneumococcal and rotavirus ranging between 35-47\%, falling significantly short of the WHO's recommended coverage of $>90 \%$. Although many different factors affect these figures, vaccination compliance is one of the major obstacles to broader immunisation coverage globally. Pain that is felt during parenteral vaccine administration is one of the most frequently reported causes of vaccine hesitancy. Success of the oral polio vaccine in bringing the disease close to eradication (notwithstanding recent issues related to the vaccine itself [1]), and the increasing uptake of the nasal flu vaccine for children, indicate that non-injectable routes of vaccination have a significant impact on improving coverage and compliance. Vaccines also have a critical role in slowing down and preventing the spread of antibiotic resistance worldwide [2]. Approaches to broaden vaccination coverage include the development of new technologies for the mode and route of vaccine administration, and formulations for cutaneous, oral and mucosal delivery (Figure 1). We discuss here the targeted strategies and key innovations of different vaccination technologies, highlighting their potential to overcome common vaccination-related limitations and improve compliance.

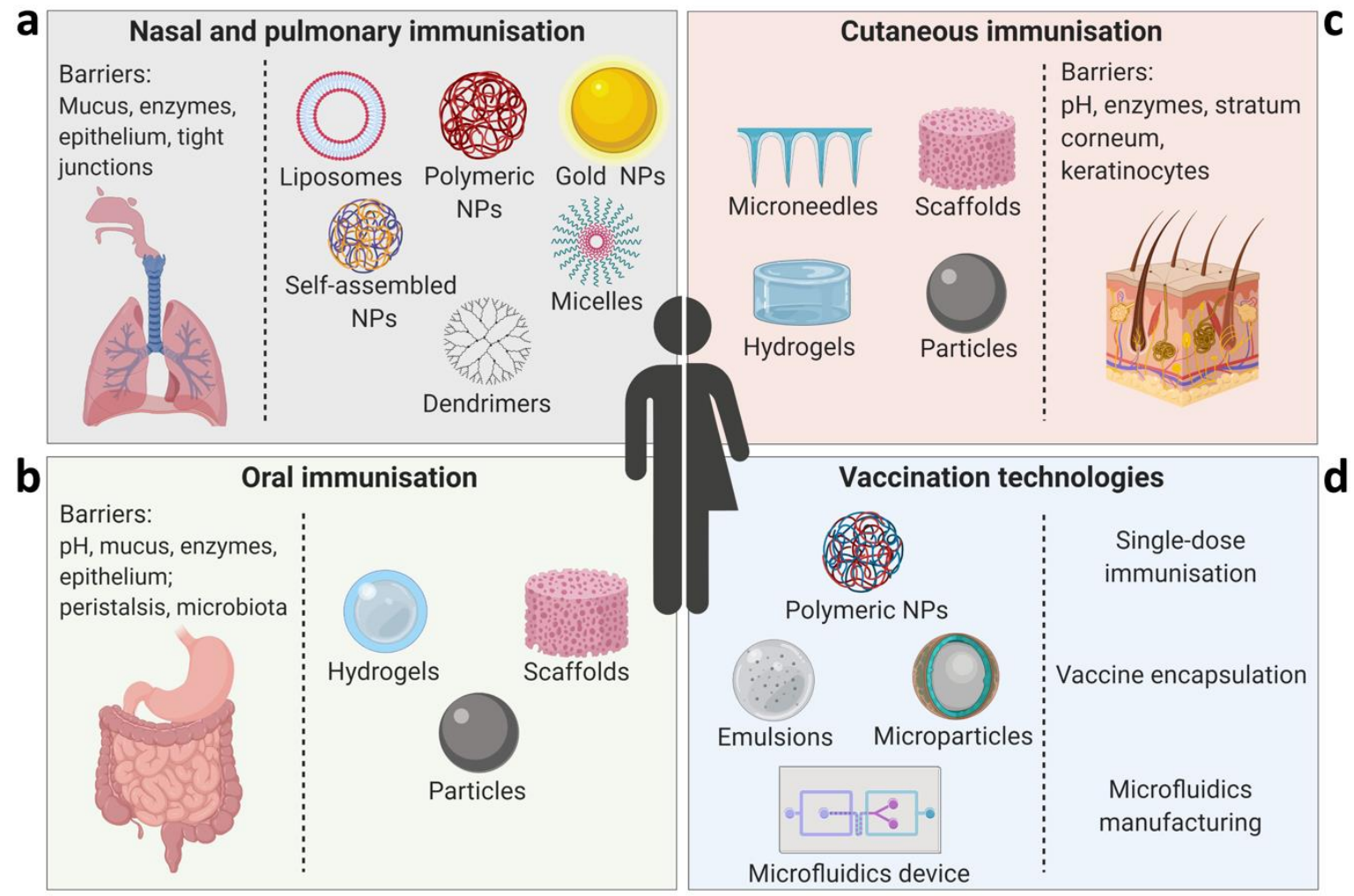

Figure 1. Advanced vaccination technologies and strategies for improving compliance and coverage. Key drug delivery systems to overcome barriers associated with each administration route are presented: (a) nasal and pulmonary immunisation using particulate delivery systems such as lipid-based systems (liposomes or nanocapsules), polymeric nanoparticles (NPs), gold NPs, self-assembled NPs (e.g., chitosan), dendrimers, and micelles; (b) oral immunisation using delivery systems such as hydrogels, scaffolds, and particles (nano- and microparticles); (c) cutaneous immunisation can be performed using microneedles, scaffolds, hydrogels, nano- and microparticles; (d) advanced technologies for improving vaccine manufacture and delivery, such as single-dose immunisation using polymeric NPs, and vaccine encapsulation using emulsions or microfluidics systems. Figure prepared using BioRender. 


\section{Vaccine Formulations for Pulmonary and Nasal Delivery}

Mucosal immunity is the first and foremost line of defence against pathogens that enter the body through the oral mucosa and the nasal cavity, such as influenza and viruses causing meningitis, measles or whooping cough. Estimates of the surface area of the mucus membranes lining the lungs vary between 50-75 square meters, representing the largest epithelial surface exposed to the outside environment. However, most licensed vaccines are administered by intramuscular injection, which preferentially induces systemic immune responses [3]. Protective mucosal responses can be effectively elicited by mucosal immunisation [4]; furthermore, mucosal vaccines are attractive by being non-invasive and needle-free.

The airway mucosa is the site of substantial immunological activity where constant immune monitoring recruits highly professional innate and adaptive immune cells, to protect the host from microbial and environmental insults. Nasopharynx-associated lymphoid tissue (NALT) is an organised mucosal immune system that consists of lymphoid tissue, B cells, T cells and antigen presenting cells (APCs), covered by an epithelial layer containing microfold (M) cells [5]. M cells in the epithelial cell layers have a specialised role in transporting antigens across the epithelium $[5,6]$. Following mucosal administration, immunity is induced at mucosal as well as serosal surfaces and in both local and distal mucosa. Compared to conventional injectable vaccines, mucosal vaccines have many other advantages: ease of administration, better patient compliance, lower costs, avoidance of needle stick injuries and needle waste, and the scope for mass immunisation [7]. The interconnection of various mucosal sites through a common mucosal immune system allows the possibility to immunise via the nose against infectious diseases that originate from distal mucosal sites [8].

Intranasal administration of a vaccine allows the induction of a strong systemic and local immune response. In a recent phase I clinical trial of a novel intranasal respiratory syncytial virus (RSV) F protein vaccine, which was linked to an immunostimulatory bacterium-like particle, persistent nasal IgA and serum IgG responses were observed for up to six months [9]. In addition, the enzymatic activity in the nasal cavity is relatively weak, compared to the oral route, which can be a reason why some vaccines are more efficient when administered intranasally. In a study that compared the mucosal delivery of the intranasal and oral Bordetella bronchiseptica vaccine, the intranasal vaccine conferred stronger clinical immunity [10]. However, antigens can also be rapidly removed from the nasal cavity or poorly absorbed by epithelial cells, potentially leading to reduced immunogenicity [11]. Nasal vaccines can be delivered in the form of powder, aerosol, gel or drops. Each of these forms have their advantages and disadvantages, as reviewed previously [12].

Mucosal vaccination can protect against several mucosally transmitted bacterial and viral diseases, and a few oral and nasal mucosal vaccines have been authorised for use in humans e.g., sabin polio, rotavirus, and nasal influenza vaccine [7]. All of these mucosal vaccines are based on the entire pathogen, either killed or live attenuated. Thus, they are associated with many disadvantages including laborious and expensive production and distribution, and the risk of reversion to the virulent form.

Conversely, the new generation of subunit vaccines that are based on single or multiple highly purified pathogenic antigens, such as peptides, proteins, polysaccharides, and nucleic acids, represent safer alternatives. Such subunit vaccines are inherently poorly immunogenic and require the inclusion of an adjuvant. This is especially relevant for mucosal delivery routes where the targeted mucosal epithelium, which naturally is in contact with many possible antigens, requires a strong immune-potentiating signal in order not to induce tolerance [13]. Subunit vaccines for pulmonary and nasal immunisation, when combined with adjuvants, can overcome many of the shortcomings of conventional vaccines. Table 1 summarises the vaccines delivered through pulmonary and nasal routes in different phases of clinical testing.

Adjuvants comprise structurally diverse compounds, which can be categorised as delivery systems or immunopotentiators, or a combination of both [14]. Delivery systems enhance the immune response against the co-delivered antigen by protecting it from degradation and allowing sustained antigen release. Different classes of delivery systems that can be used as a platform technology for delivering 
vaccines include liposomes, polymer particles, inorganic particles, bacterial or viral vectors, outer membrane vesicles, immunostimulating complexes, emulsions, and virus-like particles (Table 2). These vaccine carriers can extend the residence time of the antigen on the mucosa, which increases its chances of getting into the deeper layers and reaching the immune cells [15]. Different strategies can be used to deliver vaccine antigen to the mucosa: mucoadhesion, $\mathrm{M}$ cell targeting or targeting APCs. Mucoadhesion can be achieved by employing positively charged carriers such as chitosan or liposomes.

Endocine $^{\mathrm{TM}}$ is a mucosal adjuvant based on endogenous lipids found in the human body that possess a negative charge. It was shown to be both safe and effective in inducing a humoral and cell-mediated immune (CMI) response after intranasal administration in animal models, including in aged mice [16]. A positively charged oil-in-water nanoemulsion, when combined with the H5 hemagglutinin antigen, was recently shown to be effective in protecting against influenza challenge in ferrets [17]. A carrier composed of liposomes covered with chitosan induced both systemic and mucosal immunity in mice when administered intranasally together with an epitope from group A Streptococcus protein [18]. There are many specific targets on the M cell surface that can be used for designing an efficient vaccine carrier [19]. Khan et al. used a conjugate of GB-1 M cell ligand and F and G protein fragments from RSV to vaccinate mice intranasally and reported an efficient mucosal and systemic response, as well as protection against nasal challenge with RSV [20]. The conjugation of chitosan with mannose increases its engulfment by dendritic cells (DCs) and macrophages, as these cells express the mannose receptor on their surface. Mannosylated chitosan used in a DNA vaccine against M. tuberculosis administered intranasally to mice-induced secretory $\operatorname{IgA}(\operatorname{sigA})$ in the broncho-alveolar lavage (BAL) fluid and provided improved protection in challenge experiments [21]. Another example is the use of $\beta$-glucan which is recognised by the Dectin-1 receptor localised on DCs [22]. The addition of $\beta$-glucan to chitosan-HbsAg vaccine significantly increased the anti-HbsAg antibody titre in immunised mice [23]. It has to be underlined that in some cases the exact mechanism of APC targeting is unknown. DOTAP/DC-chol liposomes administered intranasally with pneumococcal surface protein A provided protection against pneumococcal infection, and were shown to be specifically engulfed by DCs, even though these particles do not possess any known DC ligands [24].

Immunopotentiators activate the immune system through pattern-recognition receptors (PRRs) expressed by APCs. Immunopotentiators can be bacterial or viral toll-like receptor (TLR) agonists, stimulator of interferon genes (STING) agonists, and cytokines (Table 3). Delivery systems and immunopotentiators together determine the magnitude and quality of the innate immune response and the subsequent adaptive immune response specific to the co-delivered vaccine antigen. Vaccine antigens are delivered to dendritic cells, the most specialised APCs, initiating the differentiation of T-helper cell subsets, which in turn interact with B cells, eventually resulting in the production of antibodies (sIgA) at mucosal sites [8].

\section{Dry Powders for Pulmonary Immunisation}

Most vaccine antigens are macromolecules, such as polysaccharides, proteins, peptides, and nucleic acids, and usually are at a great risk of chemical and physical degradation in liquid formulations [25]. All vaccines lose potency over time, and the rate of potency loss is dependent on the handling and storage temperature. The delivery of vaccine antigens in the form of dry powder particles to the lungs is recognised as a potential immunisation strategy that improves vaccine stability in comparison to liquid vaccine formulations [26]. The thermostability of vaccine antigens can be further improved by formulating them as dry powder microparticles in the presence of sugars as stabilising excipients [26]. A number of drying methods such as spray-drying, freeze-drying, and spray freeze-drying are used to prepare dry powder vaccine particles [26]. These approaches to develop thermostable vaccine formulations that are resistant to damage caused by freezing or overheating also eliminate the dependence on a cold chain. Thus, dry powder-based inhalable vaccine formulations for pulmonary immunisation not only induce systemic and mucosal immune 
responses [8], but also have logistical advantages over injectable vaccines [26]. Dry powder-based vaccine formulations have been designed and pre-clinically tested against several infectious diseases, progressing into clinical trials (Table 1). An inhalable vaccine formulation of alginate-coated live Mycobacterium microparticles was more immunogenic than liquid aerosols, and provided better protection in mice against experimental Mycobacterium tuberculosis infection [27]. In another study, an intrapulmonary-delivered Advax-adjuvanted influenza vaccine induced higher memory B and $\mathrm{T}$ cell responses than intranasal or intramuscular immunisation and conferred superior disease protection [28]. The development of inhalable dry powder vaccines is thus a promising new strategy for pulmonary immunisation. However, a number of parameters defines the optimal performance of dry powder vaccines such as aerodynamic particle size, aerosolisation performance, antigen stability, controlled release, drug delivery device, safety, and the scale-up of manufacturing. Advancements in pharmaceutical and nano-technologies enabling the development and testing of dry powder vaccines for pulmonary immunisation should help to lay the groundwork for the successful commercialisation of the first aerosolised mucosal vaccine. 
Table 1. Pulmonary and nasally delivered vaccines in clinical trials.

\begin{tabular}{|c|c|c|c|c|c|c|}
\hline Study Title & $\begin{array}{l}\text { Pathogen/ } \\
\text { Condition }\end{array}$ & Vaccine & $\begin{array}{l}\text { Administration } \\
\text { Route }\end{array}$ & Status & Phase & $\begin{array}{l}\text { Clinical Trials Gov } \\
\text { Identifier }\end{array}$ \\
\hline \multicolumn{7}{|l|}{ Intrapulmonary } \\
\hline $\begin{array}{l}\text { Phase } 1 \text { Clinical Trial of the Safety and Immunogenicity of an } \\
\text { Adenovirus-Based TB Vaccine Administered by Aerosol }\end{array}$ & Tuberculosis & Ad5Ag85A & Pulmonary & Recruiting & I & NCT02337270 \\
\hline $\begin{array}{l}\text { Investigating Immune Responses to Aerosol Bacillus } \\
\text { Calmette-Guérin (BCG) Challenge in Healthy UK Adults }\end{array}$ & Tuberculosis & BCG Danish & Pulmonary & Recruiting & I & NCT03912207 \\
\hline $\begin{array}{l}\text { ChAdOx1 85A Aerosol Versus Intramuscular Vaccination in } \\
\text { Healthy Adults (TB039) (TB039) }\end{array}$ & Tuberculosis & ChadOx1 85A & Pulmonary & Recruiting & I & NCT04121494 \\
\hline \multicolumn{7}{|l|}{ Nasal } \\
\hline $\begin{array}{l}\text { Evaluating the Safety and Immune Response to a Single Dose of } \\
\text { a respiratory syncytial virus (RSV) Vaccine in Infants and } \\
\text { Children }\end{array}$ & RSV infection & $\begin{array}{l}\text { RSV } \Delta \text { NS2 } \Delta 1313 \\
\text { I1314L }\end{array}$ & Nasal & Recruiting & I & NCT01893554 \\
\hline $\begin{array}{l}\text { Safety and Immunogenicity of a RSV Vaccine in RSV-Seropositive } \\
\text { Children and RSV-Seronegative Infants and Children }\end{array}$ & RSV infection & $\mathrm{D} 46 \mathrm{cp} \Delta \mathrm{M} 2-2$ vaccine & Nasal & $\begin{array}{l}\text { Active, not } \\
\text { recruiting }\end{array}$ & I & NCT02601612 \\
\hline $\begin{array}{l}\text { Evaluating the Infectivity, Safety, and Immunogenicity of the } \\
\text { Recombinant Live-Attenuated RSV Vaccines in } \\
\text { RSV-Seronegative Infants } 6 \text { to } 24 \text { Months of Age }\end{array}$ & RSV infection & $\begin{array}{l}\text { RSV } \\
\Delta \mathrm{NS} 2 / \Delta 1313 / \mathrm{I} 1314 \mathrm{~L} \\
\text { and RSV 276 }\end{array}$ & Nasal & $\begin{array}{l}\text { Active, not } \\
\text { recruiting }\end{array}$ & I & NCT03227029 \\
\hline $\begin{array}{l}\text { Evaluating the Infectivity, Safety, and Immunogenicity of a RSV } \\
\text { Vaccine in RSV-Seropositive Children and RSV-Seronegative } \\
\text { Infants and Children }\end{array}$ & RSV infection & RSV 6120/ANS2/1030s & Nasal & Recruiting & I & NCT03387137 \\
\hline $\begin{array}{l}\text { Evaluating the Infectivity, Safety, and Immunogenicity of the } \\
\text { Recombinant Live-Attenuated RSV Vaccines in } \\
\text { RSV-Seronegative Infants and Children } 6 \text { to } 24 \text { Months of Age }\end{array}$ & RSV infection & $\begin{array}{l}\text { RSV } \\
\begin{array}{l}\Delta \mathrm{NS} 2 / \Delta 1313 / \mathrm{I} 1314 \mathrm{~L} \\
\text { and RSV } 276\end{array}\end{array}$ & Nasal & $\begin{array}{l}\text { Active, not } \\
\text { recruiting }\end{array}$ & I & NCT03422237 \\
\hline $\begin{array}{l}\text { A Study Assessing Colonisation and Immunogenicity after Nasal } \\
\text { Inoculation with N. lactamica and Eradication on Day } 4 \text { or } 14\end{array}$ & Meningitis & Neisseria lactamica & Nasal & Recruiting & $\begin{array}{c}\text { Not } \\
\text { applicable }\end{array}$ & NCT03549325 \\
\hline $\begin{array}{l}\text { Evaluating the Infectivity, Safety and Immunogenicity of RSV } \\
\text { Vaccines in RSV-Seropositive Children and RSV-Seronegative } \\
\text { Infants and Children }\end{array}$ & RSV infection & $\begin{array}{l}\text { RSV } 6120 / \Delta N S 1 \text { and } \\
\text { RSV } \\
6120 / F 1 / G 2 / \Delta N S 1\end{array}$ & Nasal & Recruiting & I & NCT03596801 \\
\hline
\end{tabular}


Table 1. Cont.

\begin{tabular}{|c|c|c|c|c|c|c|}
\hline Study Title & $\begin{array}{l}\text { Pathogen/ } \\
\text { Condition }\end{array}$ & Vaccine & $\begin{array}{l}\text { Administration } \\
\text { Route }\end{array}$ & Status & Phase & $\begin{array}{l}\text { Clinical Trials Gov } \\
\text { Identifier }\end{array}$ \\
\hline $\begin{array}{l}\text { Mucosal and Systemic Immunity after Viral Challenge of } \\
\text { Healthy Volunteers Vaccinated with Inactivated Influenza } \\
\text { Vaccine via the Intranasal Versus Intramuscular Route }\end{array}$ & Influenza & $\begin{array}{l}\text { Flucelvax: Inactivated } \\
\text { influenza vaccine }\end{array}$ & Nasal & Recruiting & II & NCT03845231 \\
\hline $\begin{array}{l}\text { Safety and Immunogenicity of a Single Dose of the Recombinant } \\
\text { Live-Attenuated RSV Vaccines or placebo, delivered as nose } \\
\text { drops to RSV-Seronegative Children } 6 \text { to } 24 \text { Months of Age }\end{array}$ & RSV infection & 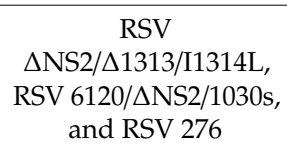 & Nasal & Recruiting & $\mathrm{I} / \mathrm{II}$ & NCT03916185 \\
\hline $\begin{array}{l}\text { Nasal and Systemic Immune Responses to Nasal Influenza } \\
\text { Vaccine (Flu-M3) }\end{array}$ & Influenza & $\begin{array}{l}\text { Live attenuated } \\
\text { influenza vaccine }\end{array}$ & Nasal & $\begin{array}{l}\text { Active, not } \\
\text { recruiting }\end{array}$ & $\begin{array}{c}\text { Not } \\
\text { applicable }\end{array}$ & NCT04110366 \\
\hline $\begin{array}{l}\text { A Controlled Study to Assess Safety, Colonisation and } \\
\text { Immunogenicity of Reconstituted Lyophilised Neisseria } \\
\text { lactamica (Lac5-Nasal) }\end{array}$ & Meningitis & $\begin{array}{l}\text { Lyophilised Neisseria } \\
\text { lactamica }\end{array}$ & Nasal & Recruiting & $\begin{array}{c}\text { Not } \\
\text { applicable }\end{array}$ & NCT04135053 \\
\hline $\begin{array}{l}\text { A Safety and Immunogenicity of Intranasal Nanoemulsion } \\
\text { Adjuvanted Recombinant Anthrax Vaccine in Healthy Adults } \\
\text { (IN NE-rPA) }\end{array}$ & Anthrax & $\begin{array}{c}\text { BW-1010: a } \\
\text { nanoemulsion } \\
\text { adjuvanted } \\
\text { recombinant protein }\end{array}$ & Nasal & Recruiting & I & NCT04148118 \\
\hline $\begin{array}{l}\text { Live-Attenuated Influenza Vaccine as a Nasal Model for } \\
\text { Influenza Infection }\end{array}$ & Influenza & $\begin{array}{l}\text { Flumist quadrivalent } \\
\text { nasal vaccine }\end{array}$ & Nasal & $\begin{array}{l}\text { Not yet } \\
\text { recruiting }\end{array}$ & IV & NCT04164212 \\
\hline
\end{tabular}

HSP, heat shock protein. 
Table 2. Delivery systems for pulmonary and nasally delivered vaccines.

\begin{tabular}{|c|c|c|c|c|c|}
\hline Delivery System & Pathogen/Antigen & Administration & Animal Model & $\begin{array}{l}\text { Immunity Type } \\
\text { Generated }\end{array}$ & Reference \\
\hline Liposomes & $\begin{array}{c}\text { Mycobacterium tuberculosis (Mtb) H56 } \\
\text { antigen }\end{array}$ & Pulmonary & Mice & Th1; Th17; IgA; IgG & [29] \\
\hline ISCOMs & $\begin{array}{c}\text { Human T cell lymphotropic virus } \\
\text { type } 1\end{array}$ & Nasal & Mice & Th1; IgA; IgG & {$[30]$} \\
\hline Chitosan & Dengue virus & Nasal & Mice & $\mathrm{CD}^{+} \mathrm{T}$ cells; IgA; IgG & [31] \\
\hline$\gamma$-polyglutamic acid & Group A Streptococcus & Nasal & Mice & $\operatorname{Ig} \mathrm{A} ; \operatorname{IgG}$ & [32] \\
\hline Hyaluronic acid & Influenza hemagglutinin & Nasal & Mice, Rabbits, Micro-pigs & $\operatorname{Ig} \mathrm{A} ; \operatorname{Ig} \mathrm{I}$ & [33] \\
\hline Pullulan & Streptococcus pneumoniae & Nasal & Macaques & Th2; Th17; IgA; IgG & [34] \\
\hline \multicolumn{6}{|l|}{$\begin{array}{l}\text { Synthetic polymer-based } \\
\text { particles }\end{array}$} \\
\hline PLGA & Chlamydia trachomatis & Nasal & Mice & Th1; IgA; IgG & [35] \\
\hline PEI & H9N2 Influenza & Nasal & Mice & $\begin{array}{l}\text { Th1; CD8 }{ }^{+} \text {T cells; } \operatorname{IgA} ; \\
\text { IgG }\end{array}$ & {$[36]$} \\
\hline PCL & Hepatitis B & Nasal & Mice & $\operatorname{Ig} \mathrm{A} ; \operatorname{IgG}$ & [37] \\
\hline PPS & $M t b$ & Nasal & Mice & Th1; Th17 & {$[38]$} \\
\hline \multicolumn{6}{|l|}{ Inorganic particles } \\
\hline Gold particles & H3N2 hemagglutinin & Nasal & Mice & $\begin{array}{c}\text { Th1; CD8 }{ }^{+} \text {T cells; IgA; } \\
\text { IgG }\end{array}$ & {$[39]$} \\
\hline Aluminium particles & Ovalbumin & Nasal & Rats & $\operatorname{IgA} ; \operatorname{IgG}$ & [40] \\
\hline Calcium phosphate particles & Chimeric dengue virus serotype 2 & Nasal & Mice & $\operatorname{Ig} A$ & [41] \\
\hline Silica-based particles & Foot and mouth disease virus & Nasal & Guinea pigs & $\operatorname{IgA} ; \operatorname{IgG}$ & [42] \\
\hline Carbon nanoparticles & Ovalbumin & Nasal & Mice & Th1; $\mathrm{CD}^{+} \mathrm{T}$ cells & [43] \\
\hline \multicolumn{6}{|l|}{ Infectious materials } \\
\hline Recombinant bacteria & $\begin{array}{l}\text { Lactobacillus plantarum vector for } \\
\text { Mtb }\end{array}$ & Nasal & Mice & Th1; IgA & [44] \\
\hline Recombinant virus & $\begin{array}{l}\text { Influenza virus vector for respiratory } \\
\text { syncytial virus }\end{array}$ & Pulmonary; Nasal & Mice & $\mathrm{CD}^{+} \mathrm{T}$ cells & [45] \\
\hline $\begin{array}{l}\text { Outer membrane vesicles } \\
\qquad(\mathrm{OMV})\end{array}$ & $\begin{array}{l}\text { Bacteroides thetaiotaomicron OMV } \\
\text { for Yersinia pestis } \mathrm{V} \text { and } \mathrm{F} \text { antigen }\end{array}$ & Nasal & Mice & $\operatorname{IgA;} \operatorname{IgG}$ & {$[46]$} \\
\hline Emulsions & Helicobacter pylori & Nasal & Mice & Th1; IgA; IgG & [47] \\
\hline VLPs & Influenza VLPs & Nasal & Mice & Th1; IgA; IgG & [48] \\
\hline
\end{tabular}

HSP, heat shock protein; Ig, immunoglobulin; ISCOMs, immunostimulatory complexes; PCL, poly $\varepsilon$-caprolactone; PEI, polyethyleneimine; PLGA, poly (lactic-co-glycolic acid);

PPS, polyphenylene sulphide; Th, helper T cells; VLPs, virus-like particles. 
Table 3. Immunopotentiators for pulmonary and nasally delivered vaccines.

\begin{tabular}{|c|c|c|c|c|c|}
\hline Immunopotentiator & Pathogen/Antigen & Administration & Animal Model & $\begin{array}{l}\text { Immunity Type } \\
\text { Generated }\end{array}$ & Reference \\
\hline \multirow{3}{*}{$\begin{array}{l}\text { Bacterial TLR agonists } \\
\text { Lipopeptides: TLR-1/2 agonists } \\
\text { Lipopolysaccharide: TLR-4 } \\
\text { agonist }\end{array}$} & \multirow{3}{*}{$\begin{array}{c}\text { Mycobacterium tuberculosis } \\
\text { Human T cell lymphotropic virus } \\
\text { type } 1\end{array}$} & & & \multirow[b]{2}{*}{ Th1; Th17 } & \multirow[b]{2}{*}{ [49] } \\
\hline & & Nasal & Mice & & \\
\hline & & Nasal & Mice & Th1; IgA; IgG & [30] \\
\hline $\begin{array}{l}\text { Peptidoglycan: TLR-2/4 } \\
\text { agonists }\end{array}$ & Respiratory syncytial virus & Nasal & Mice & Th1; Th2 & {$[50]$} \\
\hline Flagellin: TLR-5 agonist & Influenza A virus & Nasal & Mice & $\begin{array}{l}\text { Th1; CD8 }{ }^{+} \mathrm{T} \text { cells; IgA; } \\
\text { IgG }\end{array}$ & {$[51]$} \\
\hline CpG DNA: TLR-9 agonist & Foot and mouth disease virus & Nasal & Guinea pig & $\operatorname{Ig} \mathrm{A} ; \operatorname{IgG}$ & [42] \\
\hline \multicolumn{6}{|l|}{ Viral TLR agonists } \\
\hline $\begin{array}{c}\text { Double stranded RNA: TLR } 3 \\
\text { agonist }\end{array}$ & $\begin{array}{c}\text { Human parainfluenza virus type } 3 \\
\text { virus }\end{array}$ & Nasal & Mice; Cotton rats; Pigs & Th1; IgA & [52] \\
\hline $\begin{array}{l}\text { Guanosine analogues: TLR-7/8 } \\
\text { agonists }\end{array}$ & Entamoeba histolytica & Nasal & Mice & Th1; Th17; IgA; IgG & [53] \\
\hline $\begin{array}{l}\text { STING agonist: Cyclic } \\
\text { dinucleotide GMP-AMP }\end{array}$ & H1N1, H3N2, H5N1, H7N9 Influenza & Nasal & Mice; Ferrets & $\begin{array}{l}\text { Th1; CD8 }{ }^{+} \text {T cells; } \operatorname{IgA} ; \\
\text { IgG }\end{array}$ & {$[54]$} \\
\hline \multicolumn{6}{|l|}{ Cytokines } \\
\hline Type I Interferons (IFN) & Influenza & Nasal & Mice & $\operatorname{Ig} A ; \operatorname{IgG}$ & {$[55]$} \\
\hline IFN- $\gamma$ & Yersinia pestis & Nasal & Mice & $\operatorname{Ig} A ; \operatorname{IgG}$ & [56] \\
\hline GM-CSF & HIV-1 & Nasal & Mice & $\operatorname{IgA} ; \operatorname{IgG}$ & [57] \\
\hline IL-12 & HIV & Nasal & Mice & $\begin{array}{l}\text { Th1; CD8 }{ }^{+} \text {T cells; IgA; } \\
\text { IgG }\end{array}$ & [58] \\
\hline IL-15 & Simian immunodeficiency virus & Pulmonary & Mice & Th1; CD8 ${ }^{+}$T cells; ADCC & [59] \\
\hline IL-18 & HIV & Nasal & Mice & Th1; CD ${ }^{+} \mathrm{T}$ cells & {$[60]$} \\
\hline FLT-3 ligand & Chlamydia abortus & Nasal & Mice & Th1; IgA; IgG & [61] \\
\hline
\end{tabular}

ADCC, antibody-dependent cell-mediated cytotoxicity; CpG, cytidine-phosphateguanosine; FLT-3, Fms-Like tyrosine kinase 3; GM-CSF, granulocyte-macrophage colony-stimulating factor; GMP-AMP, guanosine monophosphate-adenosine monophosphate; HIV, human immunodeficiency virus; HN, hemagglutinin and neuraminidase; IL, interleukin; STING, stimulator of

interferon genes; TLR, toll-like receptor. 


\section{Oral (Gastrointestinal) Vaccines}

Oral delivery is the most patient-friendly route of administration, and consequently, oral vaccines have the potential to improve vaccine efficacy by enhancing their accessibility and distribution, which may lead to better vaccine coverage [3]. Oral vaccination is also regarded as the optimal means to fight infections caused by enteric pathogens as it induces intestinal immunity through the gut-associated mucosal tissues [62]. The first successfully implemented oral vaccine was the oral polio vaccine developed in the 1950s by Albert Sabin. It had the ability to induce protective sIgA responses in the intestinal mucosa, the main site of poliovirus entry and multiplication. This significantly reduced viral transmission, leading towards the global eradication of polio [8]. Other licensed oral vaccines target diseases induced by enteric pathogens such as Vibrio cholerae, Salmonella typhi and rotavirus, causing cholera, typhoid fever and gastroenteritis, respectively [63].

Despite the clear benefits of oral vaccines, only a few have been successfully developed. Oral vaccines have to overcome difficult challenges linked to the gastrointestinal biology: the acidic environment in the stomach, the proteolytic enzymes necessary for protein degradation, the presence of mucus, low intestinal permeability and the generally poor immunogenicity of orally delivered antigens [64]. Consequently, an efficient oral vaccine should ideally be (1) stable in a highly enzymatic environment and resistant to site-specific $\mathrm{pH}$; (2) delivered to specific immune-induction sites (e.g., Peyer's patches in the small intestine); (3) adapted to interactions with mucus; (4) able to be transported through the intestinal epithelial barrier; (5) captured by appropriate APCs and able to evade mucosal tolerance [19]. A number of oral drug delivery technologies are currently under pre-clinical and clinical development to overcome these challenges [65]. Various particle-, liposomalor adenoviral-based systems have been evaluated as vehicles to deliver the vaccine antigens [62]. Other promising formulations are site-specific delivery systems, which are often capsule- or tablet-based. These systems can facilitate antigen protection and the delivery of vaccines to specific areas of the gastrointestinal tract and particularly to the key sampling sites such as the Peyer's patches [19]. Site-specific release can be achieved through the application of $\mathrm{pH}$-dependent coating such as shellac, cellulose acetate phthalate, cellulose acetate trimellitate, poly(vinyl acetate phthalate), or hydroxypropyl methylcellulose phthalate [66]. These delivery systems play an important role in the stability and the delivery efficacy of vaccine components to the intestine. However, additional targeted strategies to specifically induce intestinal immune responses may be beneficial.

Ligand-mediated vaccine delivery systems have been shown to direct antigens to specific receptors expressed on intestinal M cells, epithelial cells or intestinal APCs [19]. Given the pivotal role of M cells in antigen sampling, several lectin-, antibody- and peptide-based targeted strategies have been developed to specifically engage these cells. Plant lectin-based ligands, facilitating the bioadhesion to glycans expressed on M cells, have been tested. Ulex europaeus agglutinin-1 (UEA-1) was shown to specifically bind to $\alpha$-L-fucose residues expressed on mouse Peyer's patch M cells $[67,68]$ and able to target polystyrene microparticles [69] or liposomes [70] to them. Since many intestinal pathogens gain entry to the host through $\mathrm{M}$ cells, some $\mathrm{M}$ cell receptors used by bacteria have also been evaluated. For example, glycoprotein 2 (GP2) is expressed on murine and human intestinal M cells, and Escherichia coli (E. coli) and Salmonella enterica typhimurium are able to bind GP2 through FimH, a pili component on the bacterial outer membrane [71]. The conjugation of an anti-GP2 monoclonal antibody to ovalbumin (OVA) resulted in effective $M$ cell targeting and oral immunisation with this system triggering enhanced faecal OVA-specific sIgA responses compared to the antigen alone in mice [72]. Other M cell-specific antibodies have been analysed. The conjugation of the anti-M cell antibody $5 \mathrm{~B} 11$ to polystyrene particles enhanced their uptake by rabbit intestinal $\mathrm{M}$ cells in an ileal loop model [73], while oral vaccination with a conjugate of the NKM 16-2-4 antibody to botulinum toxoid (BT) enhanced BT-specific serum IgG and mucosal IgA responses as well as protective immunity against lethal challenge with BT in mice [74]. Finally, some peptides targeting $M$ cells have been tested by oral route. The tripeptide Arginine-Glycine-Aspartic Acid (RGD) motif, which could bind to $\beta$-integrins on $\mathrm{M}$ cells, was shown to enhance antigen-specific serum IgG responses in mice [75] and the tetragalloyl-D-lysine dendrimer 
(TGDK) targeting murine, human, and nonhuman primate $\mathrm{M}$ cells was demonstrated to enhance faecal antigen-specific IgA responses in macaques [76].

In addition to targeted strategies to engage specific cells, including $M$ cells, the choice of antigen and adjuvant is pivotal in developing efficient oral vaccines. The current licensed oral vaccines are composed of either live-attenuated or killed organisms, sometimes in combination with protein subunit components [77]. To enhance the antigen immunogenicity, novel recombinant enterotoxigenic E. coli (ETEC) [78] and Vibrio cholerae [79] strains, overexpressing antigens or expressing multiple antigens, have been developed and were successfully tested in animal models and in clinical trials. Considering that much vaccine development is currently focused on subunit vaccines, the addition of adjuvants to the formulation may be crucial to overcome intestinal tolerance. However, there are currently no licensed adjuvanted oral vaccines for human use.

Cholera toxin (CT) and the heat-labile enterotoxin of E. coli (LT) have been shown to be potent mucosal adjuvants in pre-clinical studies. However, the native forms of these toxins are too toxic for use in humans, leading some research groups to develop toxin or toxin subunit mutants [77]. For instance, double-mutant labile toxin (dmLT) has been tested in pre-clinical studies [80] and evaluated in a Phase I clinical trial as part of a prototype oral ETEC vaccine [81]. Interestingly, dmLT was shown to promote Th17 responses but also protective sIgA responses in pre-clinical studies [82]. A non-toxic CT derivative was also developed as CTA1-DD which is a fusion between the A subunit of CT and the D-fragment of the Staphylococcus aureus protein A [83]. CTA1-DD was shown to be safe and enhanced the immunogenicity of various antigens in animal models [84].

Unconventional $\mathrm{T}$ cells such as invariant natural killer $\mathrm{T}$ (iNKT) cells or mucosal-associated invariant T (MAIT) cells have been considered as potential adjuvant targets: Intestinal sites are enriched in these cells which are at the interface between innate and adaptive immunity and can modulate APCs [85]. Some iNKT cell agonists have been investigated as adjuvants to enhance immune responses in immunotherapy and vaccination strategies [86]. Lavelle and colleagues demonstrated the potential of the iNKT cell activator $\alpha$-Galactosylceramide ( $\alpha$-GalCer) as an oral adjuvant to enhance intestinal immune responses induced by experimental whole-cell killed ETEC [87], Vibrio cholerae [88] and Helicobacter pylori [89] antigens in mouse models. In addition, a novel oral delivery-integrated system named Single Multiple Pill ${ }^{\circledR}\left(\mathrm{SmPill}^{\circledR}\right)$, containing oil-in-water emulsions formulated as $1 \mathrm{~mm}$ minispheres, was reported to effectively protect and enhance the release of various drugs in targeted intestinal regions [90]. The SmPill ${ }^{\circledR}$ integrated system, incorporating a recombinant formalin-killed whole-cell E. coli overexpressing the colonisation factor antigen I (CFA/I) and the orally active adjuvant $\alpha$-GalCer, was shown to facilitate a controlled and sustained antigen release at intestinal $\mathrm{pH}$ [87]. Furthermore, this vaccine delivery system was able to enhance the intestinal CFA/I-specific sIgA responses in mice. It was also shown that a novel whole-cell killed Vibrio cholerae strain and recombinant cholera toxin subunit B (CTB) could be successfully loaded as antigens in SmPill ${ }^{\circledR}$ minispheres. Consistent with the previous findings, Davitt and colleagues demonstrated that combining these antigens and $\alpha$-GalCer in SmPill ${ }^{\circledR}$ minispheres enhanced intestinal lipopolysaccharide and CTB-specific IgA responses and induced intestinal antigen-specific Th1 responses (Figure 2) [88].

Finally, a key concern in vaccine formulation is stability. Indeed, the development of thermostable vaccine formulations may improve vaccine coverage, especially in low-income countries. The stability of this integrated oral delivery system containing formalin-killed whole-cell E. coli overexpressing CFA/I, and the orally active adjuvant $\alpha$-GalCer, was evaluated under various temperature and humidity conditions. Longet and colleagues determined that SmPill ${ }^{\circledR}$ minispheres maintained both the antigenicity of CFA/I and the immunostimulatory activity of the $\alpha$-GalCer adjuvant after the storage of SmPill ${ }^{\circledR}$ minispheres under room temperature and extreme storage conditions for several months [91]. Collectively, these results support the potential of the SmPill ${ }^{\circledR}$ minisphere approach to enhance the immunogenicity of orally delivered antigens [87] and maintain the stability of oral vaccine formulations [91]. This exemplifies the potential to use integrated strategies to overcome challenges in developing oral vaccines. 


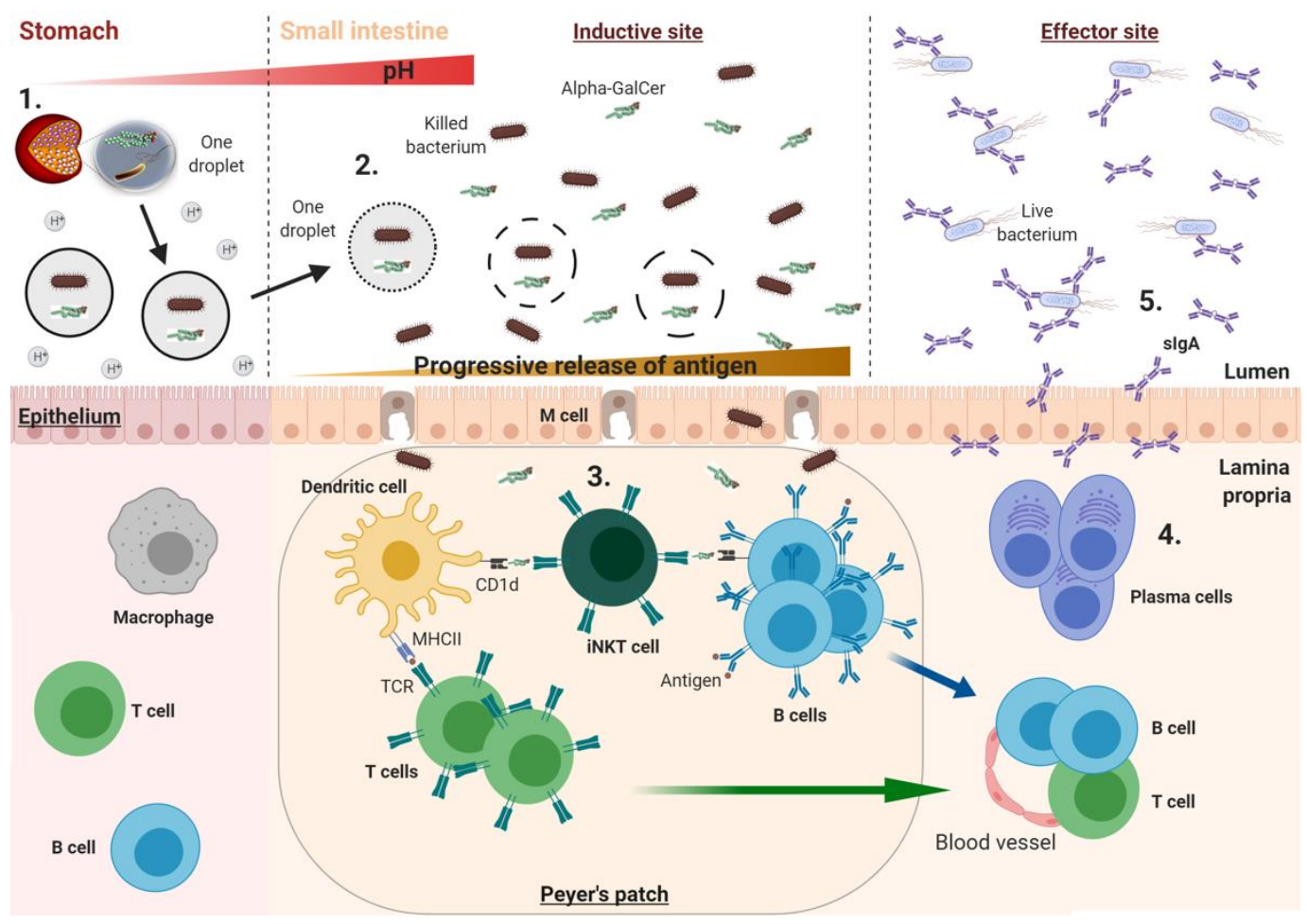

Figure 2. Proposed mechanism of the $S m P i l l{ }^{\circledR}$ minispheres and the induction of intestinal vaccine-specific immune responses: 1 . The enteric coating of SmPill ${ }^{\circledR}$ minispheres remains intact in the acidic environment of the stomach protecting the payload; 2 . On exiting the stomach and the passage into the increasing $\mathrm{pH}$ of the small intestine, the enteric coating begins to degrade, exposing the gelatine core and releasing the oil droplets containing the vaccine antigen (e.g., whole-cell killed bacteria) and the solubilised adjuvant (e.g., $\alpha$-GalCer); 3 . The payload is gradually released in the small intestine and the antigen/adjuvant can cross the intestinal epithelium (e.g., through $\mathrm{M}$ cells) where the presentation of processed whole-cell killed bacteria and $\alpha$-GalCer by DCs to T cells and invariant natural killer T (iNKT) cells occurs, respectively. This leads to B cell activation; 4 . B cells undergo affinity maturation, class switch recombination and differentiation into plasma cells, which enter into the circulation and home back to the lamina propria where antigen-specific IgA secretion occurs; 5 . Upon infection with viable bacteria, sIgA transported into the intestinal lumen can neutralise the bacteria. Figure prepared using BioRender.

\section{Cutaneous Immunisation}

Skin or (trans)cutaneous vaccination is a route of immunisation mediated by topical, intradermal (ID) or intraepidermal delivery [92]. In line with global aspirations to expand vaccination coverage, cutaneous vaccines are regarded as a promising option for overcoming diverse issues, from vaccine safety and reactogenicity to patient preferences [93]. As an immunocompetent and multi-functional organ, the skin appears to be highly susceptible to certain vaccine adjuvants, resulting in enhanced immunogenicity and allowing the reduction in antigen dose and immunisation frequency [94]. Therefore, it is important that the immunogenicity profiles of cutaneous vaccines are not significantly inferior to other routes of vaccination [93]. Among the many technological approaches for cutaneous vaccination, several deserve a more detailed overview.

Electroporation is an electro-permeabilisation method, being intensively explored in different fields: DNA manipulation in vitro, drug delivery and gene therapy. It is based on the transitory structural perturbation of lipid membranes (such as the cell membrane) through the application of high-voltage electrical impulses. Typically, electroporation involves the short-term exposure (few $\mu$ s to $\mathrm{ms}$ ) to high-voltage pulses (50-1500 V) with up to $1 \mathrm{~s}$ intervals. It is hypothesised that a structural 
rearrangement in the lipid bilayer occurs, consequently forming transient pores and facilitating molecular transport for both small molecules and biologics [95]. In the context of skin vaccine delivery, the CELLECTRA ${ }^{\circledR}$ electroporation device (developed by Inovio Pharmaceuticals) has shown good safety and efficacy [96] and is currently being assessed in a Phase III clinical study for DNA-based immunotherapy of cervical cancer (NCT03721978). It has more recently also been applied to a DNA-based coronavirus vaccine (NCT04336410). Interestingly, there are findings suggesting that electroporation alone may act as a physical adjuvant, by stimulating the 'trickling' of Langerhans cells (LCs) away from the treatment site (presumably to lymph nodes) and inducing a certain level of pro-inflammatory cytokines [97].

Among the different thermal microporation technologies, fractional infrared laser ablation stands out as particularly suitable for bypassing the skin barrier properties. It enables the disruption of the stratum corneum in a highly controlled and adjustable fashion, simultaneously providing an intrinsic adjuvanting effect. Consequently, this technology has been intensively investigated for the pain-free prophylactic and therapeutic treatment of type I allergies and tumours [92,98,99]. Despite a two-step administration process (microporation followed by antigen application), laser ablation could potentially be valuable in mass vaccination campaigns, particularly in combination with dry vaccine patches, offering advantages such as heat stability, the avoidance of needle-related injuries, and improved uptake, at a cost similar to conventional vaccination [99]. Currently, the major challenge is how to standardise the pore depth and ensure sufficient reproducibility, due to the variability of skin thickness depending on body site, age and ethnicity [92]. The available results encourage further investigations in healthy adults to evaluate the safety and efficacy of laser microporation prior to, for example, vaccine patch application [98].

Microneedle arrays represent another interesting approach for intradermal vaccine delivery. Although these devices comprise needles, their length $(10-2000 \mu \mathrm{m})$ offers relatively pain-free application [100]. Among the many microneedle types, future widespread vaccine delivery is expected for solid and dissolvable needles $[93,101]$. However, attaining reproducible coating and mechanical properties remain among the frequently noted critical attributes. Preclinical studies conducted to date imply that microneedles may generate immunogenicity comparable to intradermal or intramuscular vaccination, with some studies reporting higher and more durable antibody and cellular responses [101]. Satisfactory immune responses may be attained even without adjuvant addition or with considerably lower adjuvant doses than otherwise required, which is an important safety asset [92]. Therefore, microneedle patches are relatively cost effective, easy to produce and accepted well by the patients [102]. The fact that they allow self-administration may be the most significant factor in the further prospects for this mode of vaccine delivery [101].

In the search for an improved needle-free vaccination strategy, the application of dry vaccine powders using ballistic (powder) injectors seems to be a promising approach for delivering antigens to the skin, owing to improved vaccine stability and cold-chain independent logistics [103,104]. As a result, this technology has been recognised as potentially suitable for mass vaccination campaigns in developing countries [104]. Numerous studies show that DNA and RNA vaccines, as well as conventional vaccines in a dry state could be administered using the powder injectors [92]. However, in order to achieve the successful delivery of a particulate vaccine into the skin, apart from the design of ballistic devices, the powder properties (composition, particle size, shape, density) have to be carefully adjusted [104]. It should be emphasised that, although adequate immune responses have been observed in numerous preclinical and clinical studies, there are currently no ballistic injection products authorised for human use. The main unsolved issues are the high cost, cutaneous adverse reactions (e.g., erythema, petechiae, skin discoloration, oedema and skin flaking) and pain, that could lead to reduced patient adherence $[105,106]$.

Jet injection is another needle-free approach that delivers liquid vaccine formulations in a 2-500 $\mu \mathrm{L}$ range using a highly pressured propulsion system connected to a needle-free syringe or nozzle [92,107]. The delivery of the vaccine can occur intradermally but also subcutaneously or even intramuscularly, 
forming a depot, depending on the applied velocity and overall design. Apart from a variation in the depth of delivery, other safety-related issues are successfully circumvented by the fact that this method now utilises prefilled disposable delivery units, thus avoiding contamination. If future research focuses on achieving more cost-effective manufacturing, jet injectors may be a part of promising multi-platform systems (e.g., coupled with nanoparticulate formulations) for driving further the cutaneous vaccination approach $[107,108]$.

The aforementioned physical devices, although efficient in antigen delivery into the skin, may lead to some skin barrier damage, making them less suitable for mass vaccination under critical hygienic conditions [108,109]. As a result, there has been an increasing interest in passive delivery strategies, particularly nanocarriers, enabling antigen application to intact skin as well as improved antigen stability, sustained antigen release and increased antigenicity by mimicking the size of microorganisms [108,110,111]. Until now, different nanoparticles have been studied for this purpose, including vesicular nanocarriers (transfersomes, ethosomes, liposomes, niosomes, nanoemulsions) and solid nanoparticles (polymeric nanoparticles, silica-based nanoparticles) [92,110]. However, although nanoparticles may lead to a superior immune response compared to conventional intramuscular immunisation (particularly with an appropriate adjuvant), progress towards clinical settings has been negligible, due to difficulties in ensuring the accurate, reproducible and efficient delivery of antigen-loaded nanoparticles into the epidermal and dermal tissue $[109,111]$. Interestingly, in recent years, vaccination via the follicular route using nanoparticles, particularly non-flexible ones, has been recognised as a promising approach. It offers a $\mathrm{CD} 8^{+} \mathrm{T}$ cell-biased immune response (due to a large number of perifollicular APCs) that could be beneficial for the development of vaccines against intracellular pathogens, viruses and cancers [112]. However, it is important to emphasise that research in this area is still at an experimental stage, due to numerous factors affecting trans-follicular immunisation with nanoparticles, including particle size, surface properties (charge and composition of surface layer) and hair cycling [109].

\section{Controlled Antigen Release Delivery Systems for Single-Dose Immunisation}

Since the early 1990s, there has been extensive research on controlled release delivery systems for vaccine applications $[113,114]$. Prior to this, controlled delivery technologies were developed for a sustained delivery of drug molecules and provided the basic understanding of controlled release applications. This paved the way for delayed drug delivery technologies based on "smart" polymers, such as biodegradable microparticles, solid implants or in-site gel-forming implants [115] and the notion of developing biodegradable microparticles to accommodate prime-boost vaccine regimens within a single-dose formulation [116]. Encapsulating the booster vaccine into polymer particles should enable the pulsatile or continued release of the booster dose, that when combined with a free priming vaccine, can mimic a prime-boost regimen within a single immunisation. This approach would alleviate logistical challenges, the costs and the pressure on resources to deliver the booster doses, leading to increased vaccination compliance and coverage globally. Vaccine encapsulation also addresses the need for antigen sparing by improving immune responses through antigen shielding, controlled antigen release and adjuvanting effect due to the particulate nature of the encapsulated vaccine delivery system.

The biodegradable polymer of choice is the FDA-approved poly lactic-co-glycolic acid (PLGA), which can be formulated into nano- and microparticles using a range of methods, the most common being water-in-oil-in-water $(\mathrm{W} / \mathrm{O} / \mathrm{W})$ double emulsion solvent evaporation. An advantage of using polymer particles for vaccine delivery is that they can be adapted in size and/or structure to resemble a pathogen or to achieve the targeted delivery to promote humoral and CMI responses $[117,118]$. Particle size influences the immune response. For example, an efficient phagocytosis by macrophages may induce a more rapid immune response, while larger particles avoid the direct uptake by APCs and prolong antigen release [119-122]. Encapsulated antigens are protected from enzymatic degradation or rapid elimination in vivo, further contributing to an enhanced immune response $[117,118]$. The tuneable characteristics of the particulate vaccine delivery systems and the possibility for co-encapsulation 
or surface attachment of immunostimulatory agents play an important role in achieving the desired immune responses or adjuvant effects [123,124]. Various administration routes showing pre-clinical success have been reported for the oral, intranasal, parenteral and dermal delivery of antigens encapsulated in PLGA particles. These vaccine candidates, formulated using the W/O/W method, show great potential as a versatile vaccine delivery system and can achieve various immunologic requirements such as boosting antibody titres and inducing a CMI response. Although PLGA-based microparticles may no longer be a novel approach for vaccine delivery, there is a need for technological innovation to achieve more efficient, cost-effective, preferably solvent-free manufacturing methods of polymer-based controlled antigen-release delivery systems.

\section{Progress of PLGA Polymer Vaccine Delivery Systems}

The main method to achieve controlled antigen release has been the encapsulation into a polymer matrix by the $\mathrm{W} / \mathrm{O} / \mathrm{W}$ method. To this day, it remains the classic method that has been used to produce a wide array of particles with varying characteristics [125]. In general, for W/O/W, the primary emulsion consists of the antigen in an aqueous buffer emulsified into an 'oil' phase containing the polymer of choice in a selected solvent. This is followed by a secondary emulsification of the primary emulsion into an aqueous solution containing stabilising surfactants. Lastly, during a solidification phase the particles precipitate and harden as the solvent is evaporated. The manufacturing parameter of this method can be modified at various steps to obtain particles with the desired physicochemical characteristics. PLGA has been the most popular choice of biodegradable polymer and extensive research has demonstrated the influence of the co-polymer ratio, polymer viscosity, molecular weight, volume ratios and end caps on antigen release $[116,126,127]$. It is important to consider that it is not necessarily the PLGA polymer itself, but the particulate nature of the delivery system that allows for its immune-enhancing activity. The particulates are recognised as foreign material, triggering an immune response involving phagocytosis, the production of cytokines and the further activation of $\mathrm{T}$ cells.

The potential of encapsulated vaccines was initially demonstrated using ovalbumin (OVA). Superior IgG responses were detected in mice receiving subcutaneous immunisation of OVA encapsulated in PLGA particles $(10 \mu \mathrm{m})$ compared to OVA combined with Freund's adjuvant [113]. Liu et al. demonstrated that more efficient cross-presentation was achieved with OVA adsorbed or encapsulated into lipid-PLGA nanoparticles, exemplifying the potential to use integrated delivery strategies [128]. Numerous studies have confirmed the influence of particle size on both release kinetics and the resulting immune response [119,121]. Studies with smaller particles $(0.3-7 \mu \mathrm{m})[129]$ and larger particles $(100-150 \mu \mathrm{m})$ [130] both reported superior IgG titres after intraperitoneal administration. This highlights the difficulty of obtaining direct size and effect correlations for encapsulated vaccine delivery systems. Depending on the antigen and the desired immune response, the optimal particle size may differ greatly. Additionally, differences in the route of administration, animal models, and encapsulation efficiencies should be considered.

Alternative polymer materials have also been explored. Microparticle formulation strategies based on poly (D,L-lactic acid) (PLA) have been investigated in encapsulating various antigens including rotavirus, tetanus toxoid and Vibrio cholerae [131]. PLA particles $(2-8 \mu \mathrm{m})$ with encapsulated tetanus toxoid, administered intramuscularly to Wistar rats, induced high antibody titres. A further increase was observed when co-administered with Alhydrogel adjuvant [120,132]. The incorporation of poly (ethylene glycol) (PEG) was investigated with Vibrio cholerae-loaded PLA/PEG microparticles (4-5 $\mu \mathrm{m})$, inducing high antibody titres as well as protection against a lethal challenge after oral administration in CD-1 outbred mice [133].

The W/O/W method development includes combining PLGA with polysaccharides, or using polysaccharides alone, to formulate antigen delivery systems. A combination of PLGA and sodium alginate investigated for the intradermal delivery of encapsulated malaria peptides demonstrated that particles of $1 \mu \mathrm{m}$ induced a balanced Th1/Th2 response in BALB/c mice. In combination with immunostimulatory peptides (Arg-Gly-Asp), a strong CMI response was measured compared to the 
antigen alone or encapsulated in PLGA only [134]. Cationic polymers, such as chitosan, have been explored to formulate particles, however, these require emulsification with internal or external gelation techniques. When combined into PLGA particles, chitosan takes on an adjuvant role due to its inherent positive charge [135]. Novel functionalised dextrans have also been investigated in vaccine delivery systems [136].

The co-delivery of the encapsulated antigen and an adjuvant to enhance antigen presentation has been one of the focal points in the last decade, as characterisation methods have become increasingly advanced. Microparticle formulations containing aluminium salts and TLR9 agonist CpG oligonucleotides have shown that combining the antigen and adjuvant into a particulate delivery system can result in robust immune responses for single-dose vaccines compared to multi-immunisation schedules [124,132,137]. As mentioned above, other approaches have formulated the particles with ligands such as mannose to achieve DC targeting [21,135].

Multi-platform systems such as the single-dose pandemic influenza vaccine of recombinant outer membrane vesicles (rOMVs) encapsulated in PLGA demonstrated equivalent IgG titres to a prime and boost regimen, and protected mice against a challenge with a lethal dose of H1N1, six months post the initial vaccination. These microparticles (10-20 $\mathrm{mm}$ ), manufactured using $\mathrm{W} / \mathrm{O} / \mathrm{W}$, had a prolonged antigen release over 30 days [138]. This work demonstrates that significant results can be achieved when combining the classic W/O/W method with novel vaccine antigen technologies.

\section{Advanced Vaccine Encapsulation Methods}

The classic W/O/W emulsification method has a number of shortcomings that have impeded the successful commercial development of an encapsulated antigen in polymer microparticles for single-dose vaccines. Formulation issues and the lack of particle uniformity lead to uneven antigen release profiles, including an initial burst (release of antigen upon injection) [139]. Considerable progress has been made to develop encapsulation technologies that address the issues of antigen stability, encapsulation efficiency, particle size and distribution and the suitable release profiles [140,141].

To encapsulate antigens, stability is critical and the encapsulation method needs to be optimised for each vaccine. Antigen stability may be impaired due to mechanical and chemical stress induced during emulsification steps. Novel encapsulation technologies that use milder processing methods are likely to mitigate the mechanical stress and reduce solvent-surface interactions; one such approach is coaxial electrospraying [142]. Furthermore, antigen stability can be achieved with the co-encapsulation of stabilising additives such as hydrophilic PEG, surfactants, sugars, or protein serum albumin $[131,133,142]$. The co-encapsulation of cationic excipients such as Eudragit E, poly(L-lysine) and branched polyethylenimine has shown promising results for inactivated polio vaccine encapsulation by W/O/W into PLGA microparticles [143].

The very adaptable process parameters of the $\mathrm{W} / \mathrm{O} / \mathrm{W}$ method have allowed the optimisation of encapsulation processes to reach suitable encapsulation efficiencies. Nonetheless, the (double) emulsification step means that the encapsulation process occurs at random. The spontaneous emulsification (SE) solvent diffusion technique has been suggested as an improved method for controlled protein encapsulation. With SE, a more homogenous distribution of the encapsulated antigen is achieved, thus reducing the initial burst effect [139]. The SE method was validated by encapsulating bovine serum albumin (BSA): the in vitro release kinetics demonstrated a pulsatile-release of BSA and comparable antibody titres after a single-dose subcutaneous administration to BALB/C mice [144]. Technologies such as microfluidics and spray-drying have demonstrated the feasibility of more controlled encapsulation processes and may be critical in achieving the necessary encapsulation efficiencies for large scale vaccine manufacturing.

It has been demonstrated that the $\mathrm{W} / \mathrm{O} / \mathrm{W}$ method can be adapted to produce particles of desired size, however, it is quite difficult to achieve an extremely narrow size distribution (monodispersity). The size variation is largely due to the emulsification step, during which the particles have different droplet sizes, followed by variable precipitation rates during the solidification phase. The uniformity 
of particle size and distribution is also an important factor regarding the reproducibility and feasibility to scale up. Sieving the particles after emulsification can result in more uniform particle preparations. This is referred to as extrusion and achieved with Shirasu porous glass (SPG) beads [119,124,145]. Alternatively, encapsulation using novel microfluidic technologies may be a promising approach to achieve both adaptable particle sizes and a narrow size distribution. There remains a concern of translating laboratory-scale success to commercial-scale manufacture. Conventional emulsification methods may be inflated to a large scale of more than hundreds of litres per hour, however, there are numerous process parameters that need to be optimised individually [146]. This is an important aspect to take into consideration when validating novel antigen encapsulation technologies.

There is an increasing interest in developing core-shell particles with hydrophilic cores to maintain the microenvironment and therefore the conformation and biological integrity of the antigen [147]. They can be formulated using W/O/W method, microfluidics, or by StampEd assembly of polymer layers (SEAL), a recently reported microfabrication approach based on 3D printing [148]. Core:shell microparticles $(25 \mu \mathrm{m})$ with an acceptable size distribution (span) of 1.4 were manufactured using the $\mathrm{W} / \mathrm{O} / \mathrm{W}$ method combined with ionotropic gelation to form a sodium alginate-based hydro-core (Figure 3a,b) (Lemoine et al., unpublished). Using fluorophore labelling and confocal imaging, the core:shell structure of these particles was demonstrated and a variable distribution of the alginate cores was observed. Comparatively, core:shell particles with different shell thicknesses were manufactured by a microfluidics method. Using two microfluidic flow-focusing designs consecutively, the core and shell size of the particles were modified independently to produce two different populations, namely "thin-" and "thick-" shell particles. Both populations were highly monodispersed, with the coefficient of variation less than 5\% (Guyon et al., unpublished). Precise and identical size parameters across a population of particles could contribute to a sharper burst release of the payload, as particles are likely to exhibit the same behaviour if they are monodispersed. The identification of other significant factors affecting the release is also more tractable when the size of a particle batch is controlled. 


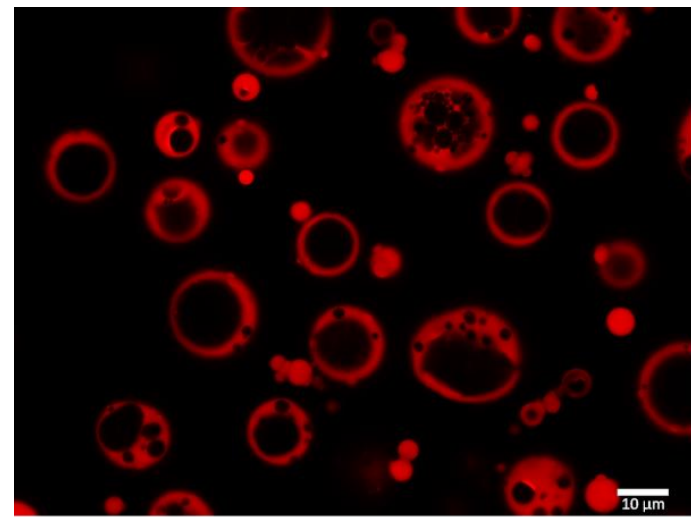

(a)

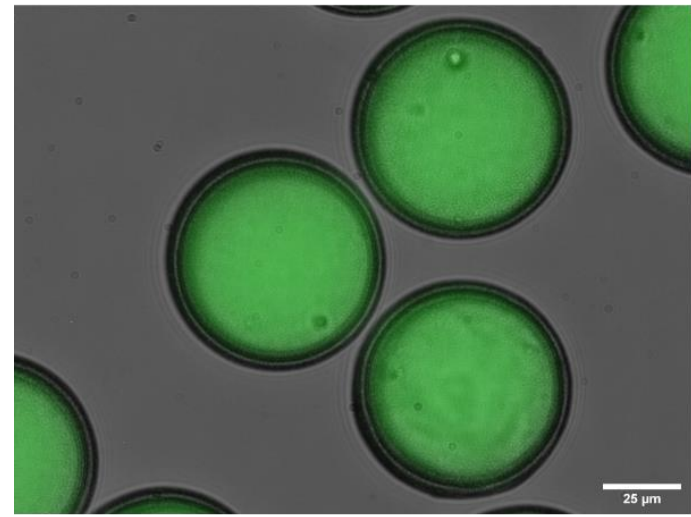

(c)

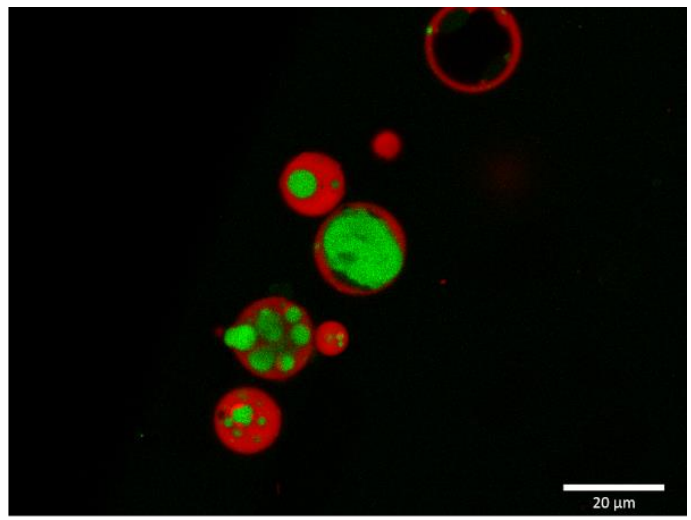

(b)

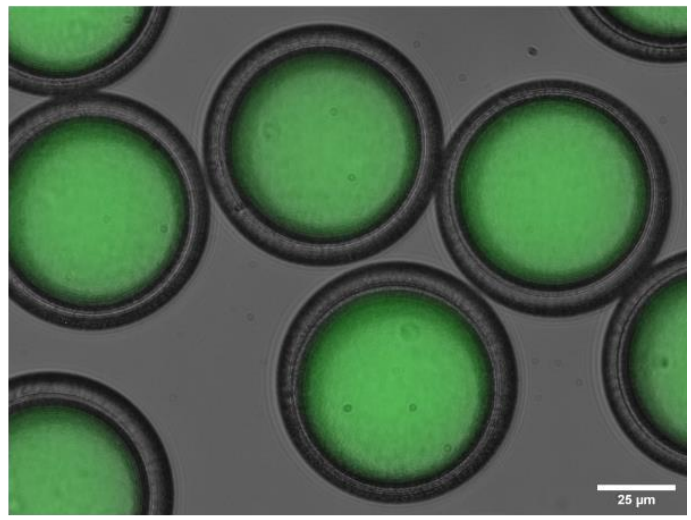

(d)

Figure 3. Core:shell microparticles prepared by two different manufacture methods. Confocal images of (a) the microparticles by the water-in-oil-in-water (W/O/W) method, core: sodium alginate 75-200 kDa (NovaMatrix ${ }^{\circledR}$ ), shell: PLGA-rhodamine (50:50 $\left.30 \mathrm{kDa}\right)$; (b) the microparticles by the W/O/W method, core: sodium alginate labelled with calcein, shell as in (a). Fluorescent microscopy images $(40 \times$ magnification) of $(\mathbf{c})$ the thin shell microparticles by the microfluidics method, core: dextran-FITC $70 \mathrm{kDa}$, shell: PLGA resomer R502 (50:50 7-17 kDa); (d) thick shell microparticles by the microfluidics method (same parameters as in (c)).

\section{Approaches to Encapsulation Using Microfluidics}

Microfluidics involves the manipulation of fluid flows at a microscale, giving the fluids a laminar behaviour, and is used in specific applications such as droplet microfluidics. Thus, microfluidics can produce highly monodispersed droplets in a controlled and repeatable manner, a feature utilised in drug delivery, and in particular for vaccine encapsulation.

In microfluidics, droplets are generated by intersection designs, where two immiscible or partially miscible phases are put into contact, and subsequently produce droplets by the combined actions of shear stress, viscous forces, and interfacial tension. This process can be conducted in capillaries assembled coaxially in "co-flow" type intersections or in microfluidic chips, often made with polydimethylsiloxane (PDMS) - a silicon polymer poured onto a mould and hardened to form microfluidic chips—or with glass, where the "T-junction" or "flow-focusing" designs are embedded. Multiple emulsions are formed with the different fluids flowing through successive intersections, generating successive layers of the multiple emulsion (see Figure 4). These template multiple emulsions, either produced by capillary microfluidics [149,150], or chip microfluidics [151,152], are then converted into microcapsules. 


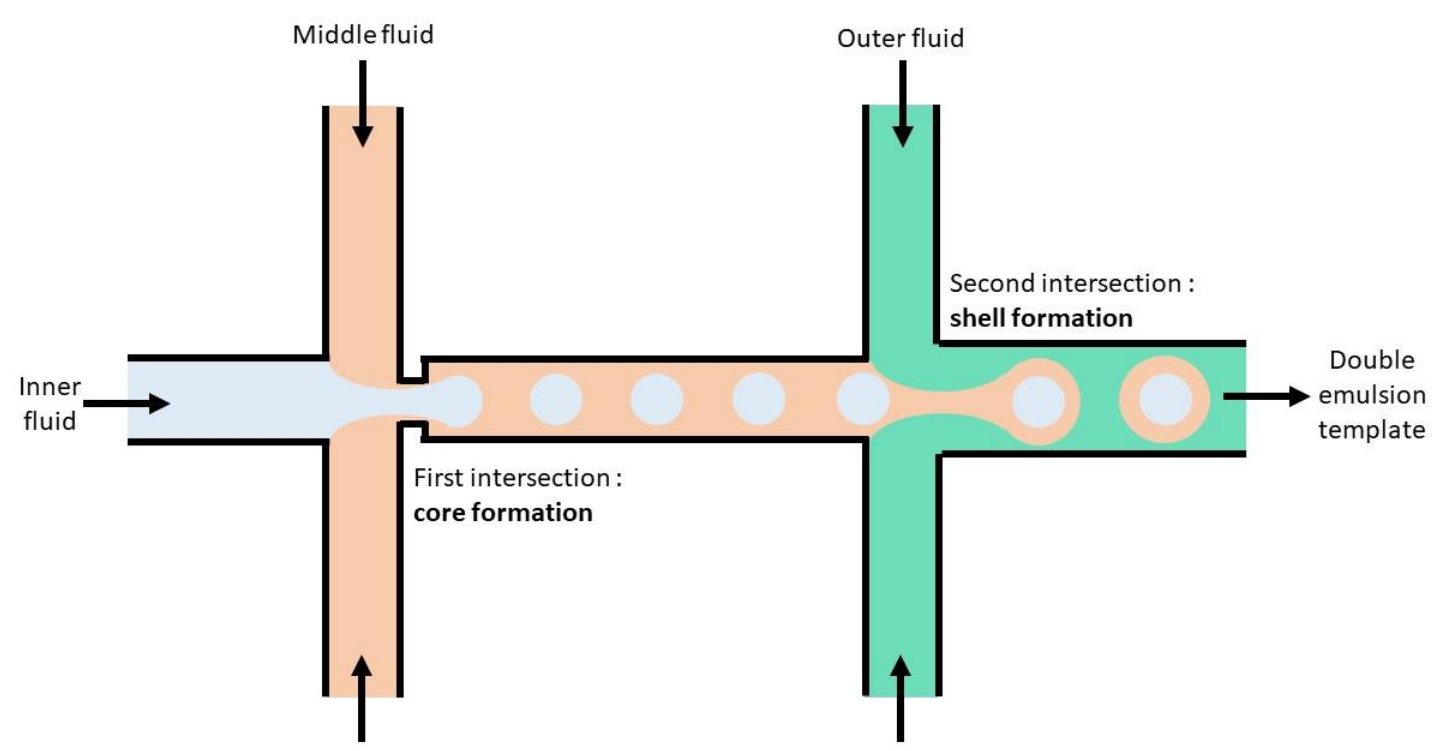

Figure 4. Double emulsion template formation by successive intersections in microfluidic chip.

\subsection{Benefits of Using Microfluidics}

As mentioned previously, the droplets generated by microfluidics exhibit an unmatched uniformity. The usual coefficient of variation (CV) of the droplet diameter is below 5\% [153,154]. This property is essential for vaccine encapsulation as the uniform size not only ensures uniform antigen loading and dosing but also enables to assess the relationship between the particle size and the antigen release kinetics without the noise brought by polydispersity.

Microfluidics also demonstrate high encapsulation efficiencies (EE) as the emulsification process is not random but happens in a user-controlled way. Thus, Pessi et al. reported a 84\% EE for BSA in polycaprolactone microcapsules produced with capillary microfluidic double emulsion [155]. Moreover, as the droplet generation occurs repeatably at a defined intersection, it minimizes the contact between the solvent phase and the antigen phase, while removing any agitation stress that takes place in classic batch emulsification methods, thus lowering the risks of loss of antigenicity.

Droplet microfluidic methods exhibit a user-friendly modularity, where the size and frequency generation can be optically monitored and changed by modifying the flow rates of the injected fluids in the microfluidic setup, as experimental law has been reported between the flow rates ratio and the size of the droplets produced [156]. This reduces the amount of post-production controls and potential waste by out-of-range production.

\subsection{Towards Implementing Microfluidics for Vaccine Delivery Systems}

Despite all the benefits of microfluidics outlined here, no direct use of this technology in the production of encapsulated vaccines for delayed delivery has been reported yet. Difficulties in setting up adequate microfluidics platform and processes could be the main reason. Indeed, microfluidics applications require both an accurate fluid flow controller, such as pressure pumps and connected reservoirs, or syringe pumps, and an imaging system, composed of a microscope, or a similar set of lenses and light, and a high-speed camera. These components are not frequently found in biology laboratories, and their setup and use also involves an engineering skill set.

Moreover, the microfluidic element itself necessitates manufacturing that has not been upscaled for mass production yet by the industry. Thus, capillary microfluidics systems are homemade, with many challenges to face in the precise assembly, while microfluidic chips are in most cases produced by soft lithography, involving clean room facilities and expertise.

The inability of microfluidics systems to achieve the yields of production needed by the drug manufacturing industry is often mentioned as one of the major drawbacks of microfluidics approaches. 
Indeed, although microfluidic droplet generation rate can reach several kilohertz, the total volume encapsulated is limited due to the inherent microscale aspect of the technology. However, parallelisation approaches, where multiple droplet microfluidic processes are performed simultaneously with the adequate designs, have been published and demonstrated more than acceptable throughputs $[146,157,158]$. Thus, Yadavali et al. reported a production rate of $277 \mathrm{~g}$ per hour of polycaprolactone microparticles using a silicon and glass parallelised microfluidic device [158].

Finally, the cost of vaccination must be kept in consideration, in particular when developing sophisticated technologies for vaccine formulation and delivery. The mobilisation of global funds for vaccine development, led by the WHO and dedicated organisations such as the Gavi Alliance, along with the scalability of methods and increasing the vaccine production capacity in the developing countries which significantly reduces the cost per dose [159], can help accelerate access to vaccines where they are most needed.

\section{Conclusions}

From the above considerations, it is evident that non-invasive vaccination systems are in development as well as are advanced delivery systems that may prove to be an essential part of promising multi-platform vaccine strategies. However, it has yet to be shown whether the presented technologies may provide reliable and cost-effective approaches to vaccination, yielding more efficient vaccines and improved patient compliance to immunisation programmes in both the developed and the developing countries.

Author Contributions: C.L., A.T., D.K., R.G., S.L., A.R., S.G., I.P., T.I., I.N., E.C.L., A.G., S.S. and A.M. have participated in the conceptualisation, writing and editing of the manuscript. All authors have read and agreed to the published version of the manuscript.

Funding: No external funding was received for writing this review.

Acknowledgments: We are grateful to the European Cooperation in Science and Technology (COST) Action CA16231 ENOVA (European Network of Vaccine Adjuvants) for supporting the networking activities that led to the publication of this manuscript.

Conflicts of Interest: The authors declare no conflict of interest. The funders had no role in the writing of the manuscript.

\section{References}

1. Roberts, L. Global polio eradication falters in the final stretch. Science 2020, 367, 14-15. [CrossRef]

2. Lewnard, J.A.; Lo, N.C.; Arinaminpathy, N.; Frost, I.; Laxminarayan, R. Childhood vaccines and antibiotic use in low- and middle-income countries. Nature 2020, 581, 94-99. [CrossRef]

3. Vela Ramirez, J.E.; Sharpe, L.A.; Peppas, N.A. Current state and challenges in developing oral vaccines. Adv. Drug. Deliv. Rev. 2017, 114, 116-131. [CrossRef]

4. Neutra, M.R.; Kozlowski, P.A. Mucosal vaccines: The promise and the challenge. Nat. Rev. Immunol. 2006, 6, 148-158. [CrossRef] [PubMed]

5. Kiyono, H.; Fukuyama, S. NALT-versus Peyer's-patch-mediated mucosal immunity. Nat. Rev. Immunol. 2004, 4, 699-710. [CrossRef]

6. Spit, B.J.; Hendriksen, E.G.; Bruijntjes, J.P.; Kuper, C.F. Nasal lymphoid tissue in the rat. Cell Tissue Res. 1989, 255, 193-198. [CrossRef]

7. Holmgren, J.; Svennerholm, A.M. Vaccines against mucosal infections. Curr. Opin. Immunol. 2012, 24, 343-353. [CrossRef]

8. Holmgren, J.; Czerkinsky, C. Mucosal immunity and vaccines. Nat. Med. 2005, 11, S45-S53. [CrossRef] [PubMed]

9. Ascough, S.; Vlachantoni, I.; Kalyan, M.; Haijema, B.-J.; Wallin-Weber, S.; Dijkstra-Tiekstra, M.; Ahmed, M.S.; van Roosmalen, M.; Grimaldi, R.; Zhang, Q. Local and Systemic Immunity against Respiratory Syncytial Virus Induced by a Novel Intranasal Vaccine. A Randomized, Double-Blind, Placebo-controlled Clinical Trial. Am. J. Respir. Crit. Care Med. 2019, 200, 481-492. [CrossRef] [PubMed] 
10. Ellis, J.A.; Gow, S.P.; Waldner, C.L.; Shields, S.; Wappel, S.; Bowers, A.; Lacoste, S.; Xu, Z.; Ball, E. Comparative efficacy of intranasal and oral vaccines against Bordetella bronchiseptica in dogs. Vet. J. 2016, 212, 71-77. [CrossRef] [PubMed]

11. Soane, R.J.; Hinchcliffe, M.; Davis, S.S.; Illum, L. Clearance characteristics of chitosan based formulations in the sheep nasal cavity. Int. J. Pharm. 2001, 217, 183-191. [CrossRef]

12. Ramvikas, M.; Arumugam, M.; Chakrabarti, S.R.; Jaganathan, K.S. Chapter Fifteen-Nasal Vaccine Delivery. In Micro and Nanotechnology in Vaccine Development; Skwarczynski, M., Toth, I., Eds.; William Andrew Publishing: New York, NY, USA, 2017; pp. 279-301.

13. Mestecky, J.; Russell, M.W.; Elson, C.O. Perspectives on mucosal vaccines: Is mucosal tolerance a barrier? J. Immunol. 2007, 179, 5633-5638. [CrossRef] [PubMed]

14. Brito, L.A.; O'Hagan, D.T. Designing and building the next generation of improved vaccine adjuvants. J. Control. Release 2014, 190, 563-579. [CrossRef] [PubMed]

15. Netsomboon, K.; Bernkop-Schnurch, A. Mucoadhesive vs. mucopenetrating particulate drug delivery. Eur. J. Pharm. Biopharm. 2016, 98, 76-89. [CrossRef] [PubMed]

16. Falkeborn, T.; Hinkula, J.; Olliver, M.; Lindberg, A.; Maltais, A.-K. The intranasal adjuvant Endocine ${ }^{\mathrm{TM}}$ enhances both systemic and mucosal immune responses in aged mice immunized with influenza antigen. Virol. J. 2017, 14, 44. [CrossRef]

17. Smith, D.; Streatfield, S.J.; Acosta, H.; Ganesan, S.; Fattom, A. A nanoemulsion-adjuvanted intranasal H5N1 influenza vaccine protects ferrets against homologous and heterologous H5N1 lethal challenge. Vaccine 2019, 37, 6162-6170. [CrossRef]

18. Nirmal, M.; Khairunnisa, A.G.; Ashwini, K.G.; Michael, R.B.; Michael, F.G.; Mariusz, S.; Istvan, T. Highly Immunogenic Trimethyl Chitosan-based Delivery System for Intranasal Lipopeptide Vaccines against Group A Streptococcus. Curr. Drug Deliv. 2017, 14, 701-708. [CrossRef]

19. Longet, S.; Lundahl, M.L.E.; Lavelle, E.C. Targeted Strategies for Mucosal Vaccination. Bioconjug. Chem. 2018, 29, 613-623. [CrossRef]

20. Khan, I.U.; Huang, J.; Li, X.; Xie, J.; Zhu, N. Nasal immunization with RSV F and G protein fragments conjugated to an $\mathrm{M}$ cell-targeting ligand induces an enhanced immune response and protection against RSV infection. Antivir. Res. 2018, 159, 95-103. [CrossRef]

21. Wu, M.; Zhao, H.; Li, M.; Yue, Y.; Xiong, S.; Xu, W. Intranasal Vaccination with Mannosylated Chitosan Formulated DNA Vaccine Enables Robust IgA and Cellular Response Induction in the Lungs of Mice and Improves Protection against Pulmonary Mycobacterial Challenge. Front. Cell. Infect. Microbiol. 2017, 7, 445. [CrossRef]

22. Willment, J.A.; Marshall, A.S.J.; Reid, D.M.; Williams, D.L.; Wong, S.Y.C.; Gordon, S.; Brown, G.D. The human $\beta$-glucan receptor is widely expressed and functionally equivalent to murine Dectin- 1 on primary cells. Eur. J. Immunol. 2005, 35, 1539-1547. [CrossRef] [PubMed]

23. Soares, E.; Jesus, S.; Borges, O. Chitosan: $\beta$-glucan particles as a new adjuvant for the hepatitis B antigen. Eur. J. Pharm. Biopharm. 2018, 131, 33-43. [CrossRef] [PubMed]

24. Tada, R.; Suzuki, H.; Takahashi, S.; Negishi, Y.; Kiyono, H.; Kunisawa, J.; Aramaki, Y. Nasal vaccination with pneumococcal surface protein A in combination with cationic liposomes consisting of DOTAP and DC-chol confers antigen-mediated protective immunity against Streptococcus pneumoniae infections in mice. Int. Immunopharmacol. 2018, 61, 385-393. [CrossRef]

25. Mahler, H.C.; Muller, R.; Friess, W.; Delille, A.; Matheus, S. Induction and analysis of aggregates in a liquid IgG1-antibody formulation. Eur. J. Pharm. Biopharm. 2005, 59, 407-417. [CrossRef]

26. Foged, C. Thermostable Subunit Vaccines for Pulmonary Delivery: How Close Are We? Curr. Pharm. Des. 2016, 22, 2561-2576. [CrossRef]

27. Nagpal, P.S.; Kesarwani, A.; Sahu, P.; Upadhyay, P. Aerosol immunization by alginate coated mycobacterium (BCG/MIP) particles provide enhanced immune response and protective efficacy than aerosol of plain mycobacterium against M.tb. H37Rv infection in mice. BMC Infect. Dis. 2019, 19, 568. [CrossRef]

28. Tomar, J.; Patil, H.P.; Bracho, G.; Tonnis, W.F.; Frijlink, H.W.; Petrovsky, N.; Vanbever, R.; Huckriede, A.; Hinrichs, W.L.J. Advax augments B and T cell responses upon influenza vaccination via the respiratory tract and enables complete protection of mice against lethal influenza virus challenge. J. Control. Release 2018, 288, 199-211. [CrossRef] 
29. Thakur, A.; Ingvarsson, P.T.; Schmidt, S.T.; Rose, F.; Andersen, P.; Christensen, D.; Foged, C. Immunological and physical evaluation of the multistage tuberculosis subunit vaccine candidate H56/CAF01 formulated as a spray-dried powder. Vaccine 2018, 36, 3331-3339. [CrossRef] [PubMed]

30. Kabiri, M.; Sankian, M.; Hosseinpour, M.; Tafaghodi, M. The novel immunogenic chimeric peptide vaccine to elicit potent cellular and mucosal immune responses against HTLV-1. Int. J. Pharm. 2018, 549, 404-414. [CrossRef] [PubMed]

31. Vemireddy, S.; Pallavi, P.; Sampath Kumar, H.M. Chitosan stabilized nasal emulsion delivery system for effective humoral and cellular response against recombinant tetravalent dengue antigen. Carbohydr. Polym. 2018, 190, 129-138. [CrossRef]

32. Nevagi, R.J.; Khalil, Z.G.; Hussein, W.M.; Powell, J.; Batzloff, M.R.; Capon, R.J.; Good, M.F.; Skwarczynski, M.; Toth, I. Polyglutamic acid-trimethyl chitosan-based intranasal peptide nano-vaccine induces potent immune responses against group A streptococcus. Acta Biomater. 2018, 80, 278-287. [CrossRef]

33. Singh, M.; Briones, M.; O'Hagan, D.T. A novel bioadhesive intranasal delivery system for inactivated influenza vaccines. J. Control. Release 2001, 70, 267-276. [CrossRef]

34. Fukuyama, Y.; Yuki, Y.; Katakai, Y.; Harada, N.; Takahashi, H.; Takeda, S.; Mejima, M.; Joo, S.; Kurokawa, S.; Sawada, S.; et al. Nanogel-based pneumococcal surface protein A nasal vaccine induces microRNA-associated Th17 cell responses with neutralizing antibodies against Streptococcus pneumoniae in macaques. Mucosal. Immunol. 2015, 8, 1144-1153. [CrossRef]

35. Rose, F.; Wern, J.E.; Gavins, F.; Andersen, P.; Follmann, F.; Foged, C. A strong adjuvant based on glycol-chitosan-coated lipid-polymer hybrid nanoparticles potentiates mucosal immune responses against the recombinant Chlamydia trachomatis fusion antigen CTH522. J. Control. Release 2018, 271, 88-97. [CrossRef] [PubMed]

36. Qin, T.; Yin, Y.; Huang, L.; Yu, Q.; Yang, Q. H9N2 influenza whole inactivated virus combined with polyethyleneimine strongly enhances mucosal and systemic immunity after intranasal immunization in mice. Clin. Vaccine Immunol. 2015, 22, 421-429. [CrossRef]

37. Jesus, S.; Soares, E.; Costa, J.; Borchard, G.; Borges, O. Immune response elicited by an intranasally delivered HBsAg low-dose adsorbed to poly-epsilon-caprolactone based nanoparticles. Int. J. Pharm. 2016, 504, 59-69. [CrossRef]

38. Shang, S.; Kats, D.; Cao, L.; Morgun, E.; Velluto, D.; He, Y.; Xu, Q.; Wang, C.R.; Scott, E.A. Induction of Mycobacterium Tuberculosis Lipid-Specific T Cell Responses by Pulmonary Delivery of Mycolic Acid-Loaded Polymeric Micellar Nanocarriers. Front. Immunol. 2018, 9, 2709. [CrossRef]

39. Wang, C.; Zhu, W.; Luo, Y.; Wang, B.Z. Gold nanoparticles conjugating recombinant influenza hemagglutinin trimers and flagellin enhanced mucosal cellular immunity. Nanomedicine 2018, 14, 1349-1360. [CrossRef]

40. Thakkar, S.G.; Warnken, Z.N.; Alzhrani, R.F.; Valdes, S.A.; Aldayel, A.M.; Xu, H.; Williams, R.O., 3rd; Cui, Z. Intranasal immunization with aluminum salt-adjuvanted dry powder vaccine. J. Control. Release 2018, 292, 111-118. [CrossRef]

41. Wang, X.; Yang, D.; Li, S.; Xu, X.; Qin, C.F.; Tang, R. Biomineralized vaccine nanohybrid for needle-free intranasal immunization. Biomaterials 2016, 106, 286-294. [CrossRef]

42. Zheng, H.; Pan, L.; Lv, J.; Zhang, Z.; Wang, Y.; Hu, W.; Liu, X.; Zhou, P.; Wang, Y.; Zhang, Y. Comparison of immune responses in guinea pigs by intranasal delivery with different nanoparticles-loaded FMDV DNA vaccine. Microb. Pathog. 2020, 142, 104061. [CrossRef]

43. Hassan, H.A.; Smyth, L.; Wang, J.T.; Costa, P.M.; Ratnasothy, K.; Diebold, S.S.; Lombardi, G.; Al-Jamal, K.T. Dual stimulation of antigen presenting cells using carbon nanotube-based vaccine delivery system for cancer immunotherapy. Biomaterials 2016, 104, 310-322. [CrossRef] [PubMed]

44. Kuczkowska, K.; Kleiveland, C.R.; Minic, R.; Moen, L.F.; Overland, L.; Tjaland, R.; Carlsen, H.; Lea, T.; Mathiesen, G.; Eijsink, V.G.H. Immunogenic Properties of Lactobacillus plantarum Producing Surface-Displayed Mycobacterium tuberculosis Antigens. Appl. Environ. Microbiol. 2016, 83, e02782-16. [CrossRef]

45. Kotomina, T.; Korenkov, D.; Matyushenko, V.; Prokopenko, P.; Rudenko, L.; Isakova-Sivak, I. Live attenuated influenza vaccine viral vector induces functional cytotoxic T-cell immune response against foreign CD8+ T-cell epitopes inserted into NA and NS1 genes using the 2A self-cleavage site. Hum. Vaccines Immunother. 2018, 14, 2964-2970. [CrossRef] 
46. Carvalho, A.L.; Miquel-Clopes, A.; Wegmann, U.; Jones, E.; Stentz, R.; Telatin, A.; Walker, N.J.; Butcher, W.A.; Brown, P.J.; Holmes, S.; et al. Use of bioengineered human commensal gut bacteria-derived microvesicles for mucosal plague vaccine delivery and immunization. Clin. Exp. Immunol. 2019, 196, 287-304. [CrossRef]

47. Yang, Y.; Chen, L.; Sun, H.W.; Guo, H.; Song, Z.; You, Y.; Yang, L.Y.; Tong, Y.N.; Gao, J.N.; Zeng, H.; et al. Epitope-loaded nanoemulsion delivery system with ability of extending antigen release elicits potent Th1 response for intranasal vaccine against Helicobacter pylori. J. Nanobiotechnol. 2019, 17, 1-15. [CrossRef]

48. Lee, Y.T.; Ko, E.J.; Lee, Y.; Kim, K.H.; Kim, M.C.; Lee, Y.N.; Kang, S.M. Intranasal vaccination with M2e5x virus-like particles induces humoral and cellular immune responses conferring cross-protection against heterosubtypic influenza viruses. PLoS ONE 2018, 13, e0190868. [CrossRef] [PubMed]

49. Ashhurst, A.S.; McDonald, D.M.; Hanna, C.C.; Stanojevic, V.A.; Britton, W.J.; Payne, R.J. Mucosal Vaccination with a Self-Adjuvanted Lipopeptide Is Immunogenic and Protective against Mycobacterium tuberculosis. J. Med. Chem. 2019, 62, 8080-8089. [CrossRef]

50. Tomosada, Y.; Chiba, E.; Zelaya, H.; Takahashi, T.; Tsukida, K.; Kitazawa, H.; Alvarez, S.; Villena, J. Nasally administered Lactobacillus rhamnosus strains differentially modulate respiratory antiviral immune responses and induce protection against respiratory syncytial virus infection. BMC Immunol. 2013, 14, 40. [CrossRef]

51. Hinkula, J.; Nystrom, S.; Devito, C.; Brave, A.; Applequist, S.E. Long-Lasting Mucosal and Systemic Immunity against Influenza A Virus Is Significantly Prolonged and Protective by Nasal Whole Influenza Immunization with Mucosal Adjuvant N3 and DNA-Plasmid Expressing Flagellin in Aging In- and Outbred Mice. Vaccines (Basel) 2019, 7, 64. [CrossRef]

52. Lin, S.F.; Jiang, P.L.; Tsai, J.S.; Huang, Y.Y.; Lin, S.Y.; Lin, J.H.; Liu, D.Z. Surface assembly of poly(I:C) on polyethyleneimine-modified gelatin nanoparticles as immunostimulatory carriers for mucosal antigen delivery. J. Biomed. Mater. Res. B Appl. Biomater. 2019, 107, 1228-1237. [CrossRef] [PubMed]

53. Abhyankar, M.M.; Orr, M.T.; Lin, S.; Suraju, M.O.; Simpson, A.; Blust, M.; Pham, T.; Guderian, J.A.; Tomai, M.A.; Elvecrog, J.; et al. Adjuvant composition and delivery route shape immune response quality and protective efficacy of a recombinant vaccine for Entamoeba histolytica. NPJ Vaccines 2018, 3, 1-10. [CrossRef] [PubMed]

54. Wang, J.; Li, P.; Yu, Y.; Fu, Y.; Jiang, H.; Lu, M.; Sun, Z.; Jiang, S.; Lu, L.; Wu, M.X. Pulmonary surfactant-biomimetic nanoparticles potentiate heterosubtypic influenza immunity. Science 2020, 367, 6480. [CrossRef]

55. Ye, L.; Ohnemus, A.; Ong, L.C.; Gad, H.H.; Hartmann, R.; Lycke, N.; Staeheli, P. Type I and Type III Interferons Differ in Their Adjuvant Activities for Influenza Vaccines. J. Virol. 2019, 93. [CrossRef]

56. Griffin, K.F.; Eyles, J.E.; Spiers, I.D.; Alpar, H.O.; Williamson, E.D. Protection against plague following immunisation with microencapsulated $\mathrm{V}$ antigen is reduced by co-encapsulation with IFN-gamma or IL-4, but not IL-6. Vaccine 2002, 20, 3650-3657. [CrossRef]

57. Matchett, W.E.; Malewana, G.B.R.; Mudrick, H.; Medlyn, M.J.; Barry, M.A. Genetic Adjuvants in Replicating Single-Cycle Adenovirus Vectors Amplify Systemic and Mucosal Immune Responses against HIV-1 Envelope. Vaccines (Basel) 2020, 8, 64. [CrossRef]

58. Maeto, C.; Rodriguez, A.M.; Holgado, M.P.; Falivene, J.; Gherardi, M.M. Novel mucosal DNA-MVA HIV vaccination in which DNA-IL-12 plus cholera toxin B subunit (CTB) cooperates to enhance cellular systemic and mucosal genital tract immunity. PLoS ONE 2014, 9, e107524. [CrossRef]

59. Demberg, T.; Boyer, J.D.; Malkevich, N.; Patterson, L.J.; Venzon, D.; Summers, E.L.; Kalisz, I.; Kalyanaraman, V.S.; Lee, E.M.; Weiner, D.B.; et al. Sequential priming with simian immunodeficiency virus (SIV) DNA vaccines, with or without encoded cytokines, and a replicating adenovirus-SIV recombinant followed by protein boosting does not control a pathogenic SIVmac251 mucosal challenge. J. Virol. 2008, 82, 10911-10921. [CrossRef] [PubMed]

60. Staats, H.F.; Bradney, C.P.; Gwinn, W.M.; Jackson, S.S.; Sempowski, G.D.; Liao, H.X.; Letvin, N.L.; Haynes, B.F. Cytokine requirements for induction of systemic and mucosal CTL after nasal immunization. J. Immunol. 2001, 167, 5386-5394. [CrossRef] [PubMed]

61. Pan, Q.; Pais, R.; Ohandjo, A.; He, C.; He, Q.; Omosun, Y.; Igietseme, J.U.; Eko, F.O. Comparative evaluation of the protective efficacy of two formulations of a recombinant Chlamydia abortus subunit candidate vaccine in a mouse model. Vaccine 2015, 33, 1865-1872. [CrossRef]

62. Kang, S.H.; Hong, S.J.; Lee, Y.K.; Cho, S. Oral Vaccine Delivery for Intestinal Immunity-Biological Basis, Barriers, Delivery System, and M Cell Targeting. Polymers (Basel) 2018, 10, 948. [CrossRef] [PubMed] 
63. Kanungo, S.; Chatterjee, P. Oral cholera vaccines: Exploring the farrago of evidence. Lancet Infect. Dis. 2017, 17, 1012-1013. [CrossRef]

64. Marasini, N.; Skwarczynski, M.; Toth, I. Oral delivery of nanoparticle-based vaccines. Expert Rev. Vaccines 2014, 13, 1361-1376. [CrossRef] [PubMed]

65. Aguirre, T.A.; Teijeiro-Osorio, D.; Rosa, M.; Coulter, I.S.; Alonso, M.J.; Brayden, D.J. Current status of selected oral peptide technologies in advanced preclinical development and in clinical trials. Adv. Drug Deliv. Rev. 2016, 106, 223-241. [CrossRef] [PubMed]

66. Al-Gousous, J.; Penning, M.; Langguth, P. Molecular insights into shellac film coats from different aqueous shellac salt solutions and effect on disintegration of enteric-coated soft gelatin capsules. Int. J. Pharm. 2015, 484, 283-291. [CrossRef] [PubMed]

67. Clark, M.A.; Jepson, M.A.; Simmons, N.L.; Booth, T.A.; Hirst, B.H. Differential expression of lectin-binding sites defines mouse intestinal M-cells. J. Histochem. Cytochem. 1993, 41, 1679-1687. [CrossRef]

68. Clark, M.A.; Jepson, M.A.; Simmons, N.L.; Hirst, B.H. Selective binding and transcytosis of Ulex europaeus 1 lectin by mouse Peyer's patch M-cells in vivo. Cell Tissue Res. 1995, 282, 455-461. [CrossRef]

69. Foster, N.; Clark, M.A.; Jepson, M.A.; Hirst, B.H. Ulex europaeus 1 lectin targets microspheres to mouse Peyer's patch M-cells in vivo. Vaccine 1998, 16, 536-541. [CrossRef]

70. Clark, M.A.; Blair, H.; Liang, L.; Brey, R.N.; Brayden, D.; Hirst, B.H. Targeting polymerised liposome vaccine carriers to intestinal M cells. Vaccine 2001, 20, 208-217. [CrossRef]

71. Hase, K.; Kawano, K.; Nochi, T.; Pontes, G.S.; Fukuda, S.; Ebisawa, M.; Kadokura, K.; Tobe, T.; Fujimura, Y.; Kawano, S.; et al. Uptake through glycoprotein 2 of $\mathrm{FimH}(+)$ bacteria by M cells initiates mucosal immune response. Nature 2009, 462, 226-230. [CrossRef]

72. Shima, H.; Watanabe, T.; Fukuda, S.; Fukuoka, S.; Ohara, O.; Ohno, H. A novel mucosal vaccine targeting Peyer's patch M cells induces protective antigen-specific IgA responses. Int. Immunol. 2014, 26, 619-625. [CrossRef]

73. Pappo, J.; Ermak, T.H.; Steger, H.J. Monoclonal antibody-directed targeting of fluorescent polystyrene microspheres to Peyer's patch M cells. Immunology 1991, 73, 277. [PubMed]

74. Nochi, T.; Yuki, Y.; Matsumura, A.; Mejima, M.; Terahara, K.; Kim, D.Y.; Fukuyama, S.; Iwatsuki-Horimoto, K.; Kawaoka, Y.; Kohda, T.; et al. A novel M cell-specific carbohydrate-targeted mucosal vaccine effectively induces antigen-specific immune responses. J. Exp. Med. 2007, 204, 2789-2796. [CrossRef] [PubMed]

75. Garinot, M.; Fievez, V.; Pourcelle, V.; Stoffelbach, F.; des Rieux, A.; Plapied, L.; Theate, I.; Freichels, H.; Jerome, C.; Marchand-Brynaert, J.; et al. PEGylated PLGA-based nanoparticles targeting M cells for oral vaccination. J. Control. Release 2007, 120, 195-204. [CrossRef] [PubMed]

76. Misumi, S.; Masuyama, M.; Takamune, N.; Nakayama, D.; Mitsumata, R.; Matsumoto, H.; Urata, N.; Takahashi, Y.; Muneoka, A.; Sukamoto, T.; et al. Targeted delivery of immunogen to primate m cells with tetragalloyl lysine dendrimer. J. Immunol. 2009, 182, 6061-6070. [CrossRef]

77. Davitt, C.J.; Lavelle, E.C. Delivery strategies to enhance oral vaccination against enteric infections. Adv. Drug Deliv. Rev. 2015, 91, 52-69. [CrossRef]

78. Holmgren, J.; Bourgeois, L.; Carlin, N.; Clements, J.; Gustafsson, B.; Lundgren, A.; Nygren, E.; Tobias, J.; Walker, R.; Svennerholm, A.M. Development and preclinical evaluation of safety and immunogenicity of an oral ETEC vaccine containing inactivated E. coli bacteria overexpressing colonization factors CFA/I, CS3, CS5 and CS6 combined with a hybrid LT/CT B subunit antigen, administered alone and together with dmLT adjuvant. Vaccine 2013, 31, 2457-2464. [CrossRef]

79. Karlsson, S.L.; Ax, E.; Nygren, E.; Kallgard, S.; Blomquist, M.; Ekman, A.; Benktander, J.; Holmgren, J.; Lebens, M. Development of stable Vibrio cholerae O1 Hikojima type vaccine strains co-expressing the Inaba and Ogawa lipopolysaccharide antigens. PLoS ONE 2014, 9, e108521. [CrossRef]

80. Leach, S.; Clements, J.D.; Kaim, J.; Lundgren, A. The adjuvant double mutant Escherichia coli heat labile toxin enhances IL-17A production in human T cells specific for bacterial vaccine antigens. PLoS ONE 2012, 7, e51718. [CrossRef]

81. Lundgren, A.; Bourgeois, L.; Carlin, N.; Clements, J.; Gustafsson, B.; Hartford, M.; Holmgren, J.; Petzold, M.; Walker, R.; Svennerholm, A.M. Safety and immunogenicity of an improved oral inactivated multivalent enterotoxigenic Escherichia coli (ETEC) vaccine administered alone and together with dmLT adjuvant in a double-blind, randomized, placebo-controlled Phase I study. Vaccine 2014, 32, 7077-7084. [CrossRef] 
82. Clements, J.D.; Norton, E.B. The Mucosal Vaccine Adjuvant LT(R192G/L211A) or dmLT. MSphere 2018, 3, e00215-18. [CrossRef] [PubMed]

83. Agren, L.C.; Ekman, L.; Lowenadler, B.; Lycke, N.Y. Genetically engineered nontoxic vaccine adjuvant that combines B cell targeting with immunomodulation by cholera toxin A1 subunit. J. Immunol. 1997, 158, 3936-3946. [PubMed]

84. Lycke, N.; Bemark, M. Mucosal adjuvants and long-term memory development with special focus on CTA1-DD and other ADP-ribosylating toxins. Mucosal. Immunol. 2010, 3, 556-566. [CrossRef] [PubMed]

85. Abautret-Daly, A.E.; Davitt, C.J.; Lavelle, E.C. Harnessing the antibacterial and immunological properties of mucosal-associated invariant $\mathrm{T}$ cells in the development of novel oral vaccines against enteric infections. Biochem. Pharmacol. 2014, 92, 173-183. [CrossRef] [PubMed]

86. Cerundolo, V.; Barral, P.; Batista, F.D. Synthetic iNKT cell-agonists as vaccine adjuvants-finding the balance. Curr. Opin. Immunol. 2010, 22, 417-424. [CrossRef] [PubMed]

87. Davitt, C.J.; McNeela, E.A.; Longet, S.; Tobias, J.; Aversa, V.; McEntee, C.P.; Rosa, M.; Coulter, I.S.; Holmgren, J.; Lavelle, E.C. A novel adjuvanted capsule based strategy for oral vaccination against infectious diarrhoeal pathogens. J. Control. Release 2016, 233, 162-173. [CrossRef] [PubMed]

88. Davitt, C.J.H.; Longet, S.; Albutti, A.; Aversa, V.; Nordqvist, S.; Hackett, B.; McEntee, C.P.; Rosa, M.; Coulter, I.S.; Lebens, M.; et al. Alpha-galactosylceramide enhances mucosal immunity to oral whole-cell cholera vaccines. Mucosal. Immunol. 2019, 12, 1055-1064. [CrossRef]

89. Longet, S.; Abautret-Daly, A.; Davitt, C.J.H.; McEntee, C.P.; Aversa, V.; Rosa, M.; Coulter, I.S.; Holmgren, J.; Raghavan, S.; Lavelle, E.C. An oral alpha-galactosylceramide adjuvanted Helicobacter pylori vaccine induces protective IL-1R- and IL-17R-dependent Th1 responses. NPJ Vaccines 2019, 4, 1-10. [CrossRef]

90. McDonald, B.F.; Coulter, I.S.; Marison, I.W. Microbeads: A novel multiparticulate drug delivery technology for increasing the solubility and dissolution of celecoxib. Pharm. Dev. Technol. 2015, 20, 211-218. [CrossRef]

91. Longet, S.; Aversa, V.; O’Donnell, D.; Tobias, J.; Rosa, M.; Holmgren, J.; Coulter, I.S.; Lavelle, E.C. Thermostability of the coating, antigen and immunostimulator in an adjuvanted oral capsule vaccine formulation. Int. J. Pharm. 2017, 534, 60-70. [CrossRef]

92. Engelke, L.; Winter, G.; Hook, S.; Engert, J. Recent insights into cutaneous immunization: How to vaccinate via the skin. Vaccine 2015, 33, 4663-4674. [CrossRef]

93. Bragazzi, N.L.; Orsi, A.; Ansaldi, F.; Gasparini, R.; Icardi, G. Fluzone(R) intra-dermal (Intanza(R)/Istivac(R) Intra-dermal): An updated overview. Hum. Vaccin. Immunother. 2016, 12, 2616-2627. [CrossRef] [PubMed]

94. Caucheteux, S.M.; Piguet, V. New Cutaneous Vaccine Adjuvant that STINGs a Little Less. J. Invest. Dermatol. 2016, 136, 2127-2128. [CrossRef] [PubMed]

95. Gupta, R.; Rai, B. Electroporation of Skin Stratum Corneum Lipid Bilayer and Molecular Mechanism of Drug Transport: A Molecular Dynamics Study. Langmuir 2018, 34, 5860-5870. [CrossRef]

96. Diehl, M.C.; Lee, J.C.; Daniels, S.E.; Tebas, P.; Khan, A.S.; Giffear, M.; Sardesai, N.Y.; Bagarazzi, M.L. Tolerability of intramuscular and intradermal delivery by CELLECTRA((R)) adaptive constant current electroporation device in healthy volunteers. Hum. Vaccines Immunother. 2013, 9, 2246-2252. [CrossRef] [PubMed]

97. Todorova, B.; Adam, L.; Culina, S.; Boisgard, R.; Martinon, F.; Cosma, A.; Ustav, M.; Kortulewski, T.; Le Grand, R.; Chapon, C. Electroporation as a vaccine delivery system and a natural adjuvant to intradermal administration of plasmid DNA in macaques. Sci. Rep. 2017, 7, 1-11. [CrossRef]

98. Herve, P.L.; Dhelft, V.; Plaquet, C.; Rousseaux, A.; Bouzereau, A.; Gaulme, L.; Tilleul, S.; Ligouis, M.; Donne, N.; Lambert, P.H.; et al. Epidermal micro-perforation potentiates the efficacy of epicutaneous vaccination. J. Control. Release 2019, 298, 12-26. [CrossRef] [PubMed]

99. Scheiblhofer, S.; Strobl, A.; Hoepflinger, V.; Thalhamer, T.; Steiner, M.; Thalhamer, J.; Weiss, R. Skin vaccination via fractional infrared laser ablation-Optimization of laser-parameters and adjuvantation. Vaccine 2017, 35, 1802-1809. [CrossRef]

100. Badizadegan, K.; Goodson, J.L.; Rota, P.A.; Thompson, K.M. The potential role of using vaccine patches to induce immunity: Platform and pathways to innovation and commercialization. Expert Rev. Vaccines 2020, 19, 175-194. [CrossRef]

101. Leone, M.; Monkare, J.; Bouwstra, J.A.; Kersten, G. Dissolving Microneedle Patches for Dermal Vaccination. Pharm. Res. 2017, 34, 2223-2240. [CrossRef] 
102. Hao, Y.; Li, W.; Zhou, X.; Yang, F.; Qian, Z. Microneedles-Based Transdermal Drug Delivery Systems: A Review. J. Biomed. Nanotechnol. 2017, 13, 1581-1597. [CrossRef]

103. Engert, J.; Anamur, C.; Engelke, L.; Fellner, C.; Lell, P.; Henke, S.; Stadler, J.; Zols, S.; Ritzmann, M.; Winter, G. A pilot study using a novel pyrotechnically driven prototype applicator for epidermal powder immunization in piglets. Int. J. Pharm. 2018, 545, 215-228. [CrossRef] [PubMed]

104. Etzl, E.E. Collapse Dried Protein Powders for Needle-Free Ballistic Injection. Ph.D. Thesis, Ludwig-Maximilians-Universität, München, Germany, 2016.

105. Tomar, J.; Born, P.A.; Frijlink, H.W.; Hinrichs, W.L. Dry influenza vaccines: Towards a stable, effective and convenient alternative to conventional parenteral influenza vaccination. Expert Rev. Vaccines 2016, 15, 1431-1447. [CrossRef] [PubMed]

106. Wallis, J.; Shenton, D.P.; Carlisle, R.C. Novel approaches for the design, delivery and administration of vaccine technologies. Clin. Exp. Immunol. 2019, 196, 189-204. [CrossRef] [PubMed]

107. Hogan, N.C.; Taberner, A.J.; Jones, L.A.; Hunter, I.W. Needle-free delivery of macromolecules through the skin using controllable jet injectors. Expert. Opin. Drug Deliv. 2015, 12, 1637-1648. [CrossRef]

108. Mittal, A.; Raber, A.S.; Lehr, C.M.; Hansen, S. Particle based vaccine formulations for transcutaneous immunization. Hum. Vaccines Immunother. 2013, 9, 1950-1955. [CrossRef]

109. Chen, Z.; Lv, Y.; Qi, J.; Zhu, Q.; Lu, Y.; Wu, W. Overcoming or circumventing the stratum corneum barrier for efficient transcutaneous immunization. Drug Discov. Today 2018, 23, 181-186. [CrossRef]

110. Gamazo, C.; Pastor, Y.; Larraneta, E.; Berzosa, M.; Irache, J.M.; Donnelly, R.F. Understanding the basis of transcutaneous vaccine delivery. Ther. Deliv. 2019, 10, 63-80. [CrossRef]

111. Pielenhofer, J.; Sohl, J.; Windbergs, M.; Langguth, P.; Radsak, M.P. Current Progress in Particle-Based Systems for Transdermal Vaccine Delivery. Front. Immunol. 2020, 11, 266. [CrossRef]

112. Hansen, S.; Lehr, C.M. Transfollicular delivery takes root: The future for vaccine design? Expert Rev. Vaccines 2014, 13, 5-7. [CrossRef]

113. O’Hagan, D.T.; Rahman, D.; McGee, J.P.; Jeffery, H.; Davies, M.C.; Williams, P.; Davis, S.S.; Challacombe, S.J. Biodegradable microparticles as controlled release antigen delivery systems. Immunology 1991, 73, 239.

114. Preis, I.; Langer, R.S. A single-step immunization by sustained antigen release. J. Immunol. Methods 1979, 28, 193-197. [CrossRef]

115. Park, K. The Controlled Drug Delivery Systems: Past Forward and Future Back. J. Control. Release Off. J. Control. Release Soc. 2014, 190, 3-8. [CrossRef] [PubMed]

116. Cleland, J. Single-administration vaccines: Controlled-release technology to mimic repeated immunizations. Trends Biotechnol. 1999, 17, 25-29. [CrossRef]

117. Leleux, J.; Roy, K. Micro and Nanoparticle-Based Delivery Systems for Vaccine Immunotherapy: An Immunological and Materials Perspective. Adv. Healthc. Mater. 2013, 2, 72-94. [CrossRef] [PubMed]

118. Silva, A.L.; Soema, P.C.; Slütter, B.; Ossendorp, F.; Jiskoot, W. PLGA particulate delivery systems for subunit vaccines: Linking particle properties to immunogenicity. Hum. Vaccines Immunother. 2016, 12, 1056-1069. [CrossRef] [PubMed]

119. Jia, J.; Zhang, W.; Liu, Q.; Yang, T.; Wang, L.; Ma, G. Adjuvanticity Regulation by Biodegradable Polymeric Nano/microparticle Size. Mol. Pharm. 2017, 14, 14-22. [CrossRef]

120. Katare, Y.K.; Muthukumaran, T.; Panda, A.K. Influence of particle size, antigen load, dose and additional adjuvant on the immune response from antigen loaded PLA microparticles. Int. J. Pharm. 2005, 301, 149-160. [CrossRef]

121. Slütter, B.; Jiskoot, W. Sizing the optimal dimensions of a vaccine delivery system: A particulate matter. Expert Opin. Drug Deliv. 2016, 13, 167-170. [CrossRef]

122. Oyewumi, M.O.; Kumar, A.; Cui, Z. Nano-microparticles as immune adjuvants: Correlating particle sizes and the resultant immune responses. Expert Rev. Vaccines 2010, 9, 1095-1107. [CrossRef]

123. Storni, T.; Kundig, T.; Senti, G.; Johansen, P. Immunity in response to particulate antigen-delivery systems. Adv. Drug Deliv. Rev. 2005, 57, 333-355. [CrossRef]

124. Zhang, W.; Wang, L.; Yang, T.; Liu, Y.; Chen, X.; Liu, Q.; Jia, J.; Ma, G. Immunopotentiator-Loaded Polymeric Microparticles as Robust Adjuvant to Improve Vaccine Efficacy. Pharm. Res. 2015, 32, 2837-2850. [CrossRef] [PubMed]

125. O'Donnell, P.B.; McGinity, J.W. Preparation of microspheres by the solvent evaporation technique. Adv. Drug Deliv. Rev. 1997, 28, 25-42. [CrossRef] 
126. Jiang, W.; Gupta, R.; Deshpande, M.; Schwendeman, S. Biodegradable poly(lactic-co-glycolic acid) microparticles for injectable delivery of vaccine antigens. Adv. Drug Deliv. Rev. 2005, 57, 391-410. [CrossRef] [PubMed]

127. Makadia, H.K.; Siegel, S.J. Poly Lactic-co-Glycolic Acid (PLGA) as Biodegradable Controlled Drug Delivery Carrier. Polymers 2011, 3, 1377-1397. [CrossRef]

128. Liu, L.; Ma, P.; Wang, H.; Zhang, C.; Sun, H.; Wang, C.; Song, C.; Leng, X.; Kong, D.; Ma, G. Immune responses to vaccines delivered by encapsulation into and/or adsorption onto cationic lipid-PLGA hybrid nanoparticles. J. Control. Release 2016, 225, 230-239. [CrossRef]

129. Joshi, V.B.; Geary, S.M.; Salem, A.K. Biodegradable Particles as Vaccine Delivery Systems: Size Matters. AAPS J. 2013, 15, 85-94. [CrossRef]

130. Gao, S.; Zhao, N.; Amer, S.; Qian, M.; Lv, M.; Zhao, Y.; Su, X.; Cao, J.; He, H.; Zhao, B. Protective efficacy of PLGA microspheres loaded with divalent DNA vaccine encoding the ompA gene of Aeromonas veronii and the hly gene of Aeromonas hydrophila in mice. Vaccine 2013, 31, 5754-5759. [CrossRef]

131. Nayak, B.; Panda, A.K.; Ray, P.; Ray, A.R. Formulation, characterization and evaluation of rotavirus encapsulated PLA and PLGA particles for oral vaccination. J. Microencapsul. 2009, 26, 154-165. [CrossRef]

132. Katare, Y.; Panda, A. Immunogenicity and lower dose requirement of polymer entrapped tetanus toxoid co-administered with alum. Vaccine 2006, 24, 3599-3608. [CrossRef]

133. Yeh, M.K.; Chiang, C.H. Inactive Vibrio cholerae whole-cell vaccine-loaded biodegradable microparticles: In vitro release and oral vaccination. J. Microencapsul. 2004, 21, 91-106. [CrossRef] [PubMed]

134. Mata, E.; Igartua, M.; Patarroyo, M.E.; Pedraz, J.L.; Hernández, R.M. Enhancing immunogenicity to PLGA microparticulate systems by incorporation of alginate and RGD-modified alginate. Eur. J. Pharm. Sci. 2011, 44, 32-40. [CrossRef] [PubMed]

135. Li, Z.; Xiong, F.; He, J.; Dai, X.; Wang, G. Surface-functionalized, pH-responsive poly(lactic-co-glycolic acid)-based microparticles for intranasal vaccine delivery: Effect of surface modification with chitosan and mannan. Eur. J. Pharm. Biopharm. 2016, 109, 24-34. [CrossRef] [PubMed]

136. Kremer, B.; Roukema, R.; Leede, L. Advances in Single-Shot Vaccine Development. BioPharm Int. 2009, 2009, $28-34$.

137. Kirby, D.J.; Rosenkrands, I.; Agger, E.M.; Andersen, P.; Coombes, A.G.A.; Perrie, Y. PLGA microspheres for the delivery of a novel subunit TB vaccine. J. Drug Target. 2008, 16, 282-293. [CrossRef]

138. Watkins, H.C.; Pagan, C.L.; Childs, H.R.; Posada, S.; Chau, A.; Rios, J.; Guarino, C.; DeLisa, M.P.; Whittaker, G.R.; Putnam, D. A single dose and long lasting vaccine against pandemic influenza through the controlled release of a heterospecies tandem M2 sequence embedded within detoxified bacterial outer membrane vesicles. Vaccine 2017, 35, 5373-5380. [CrossRef]

139. Fu, K.; Harrell, R.; Zinski, K.; Um, C.; Jaklenec, A.; Frazier, J.; Lotan, N.; Burke, P.; Klibanov, A.M.; Langer, R. A potential approach for decreasing the burst effect of protein from PLGA microspheres. J. Pharm. Sci. 2003, 92, 1582-1591. [CrossRef]

140. Han, F.Y.; Thurecht, K.J.; Whittaker, A.K.; Smith, M.T. Bioerodable PLGA-Based Microparticles for Producing Sustained-Release Drug Formulations and Strategies for Improving Drug Loading. Front. Pharmacol. 2016, 7. [CrossRef]

141. Qi, F.; Wu, J.; Li, H.; Ma, G. Recent research and development of PLGA/PLA microspheres/nanoparticles: A review in scientific and industrial aspects. Front. Chem. Sci. Eng. 2019, 13, 14-27. [CrossRef]

142. Zhang, M.; Ma, Y.; Li, R.; Zeng, J.; Li, Z.; Tang, Y.; Sun, D. RhBMP-2-loaded Poly(lactic-co-glycolic acid) microspheres fabricated by coaxial electrospraying for protein delivery. J. Biomater. Sci. Polym. Ed. 2017, 28, 2205-2219. [CrossRef]

143. Tzeng, S.Y.; McHugh, K.J.; Behrens, A.M.; Rose, S.; Sugarman, J.L.; Ferber, S.; Langer, R.; Jaklenec, A. Stabilized single-injection inactivated polio vaccine elicits a strong neutralizing immune response. Proc. Natl. Acad. Sci. USA 2018, 115, E5269-E5278. [CrossRef] [PubMed]

144. Guarecuco, R.; Lu, J.; McHugh, K.J.; Norman, J.J.; Thapa, L.S.; Lydon, E.; Langer, R.; Jaklenec, A. Immunogenicity of pulsatile-release PLGA microspheres for single-injection vaccination. Vaccine 2018, 36, 3161-3168. [CrossRef] [PubMed]

145. Yang, M.; Yang, T.; Jia, J.; Lu, T.; Wang, H.; Yan, X.; Wang, L.; Yu, L.; Zhao, Y. Fabrication and characterization of DDAB/PLA-alginate composite microcapsules as single-shot vaccine. RSC Adv. 2018, 8, 13612-13624. [CrossRef] 
146. Jeong, H.H.; Yelleswarapu, V.R.; Yadavali, S.; Issadore, D.; Lee, D. Kilo-scale droplet generation in three-dimensional monolithic elastomer device (3D MED). Lab Chip 2015, 15, 4387-4392. [CrossRef] [PubMed]

147. Rinker, T.E.; Philbrick, B.D.; Temenoff, J.S. Core-shell microparticles for protein sequestration and controlled release of a protein-laden core. Acta Biomater. 2017, 56, 91-101. [CrossRef]

148. McHugh, K.J.; Nguyen, T.D.; Linehan, A.R.; Yang, D.; Behrens, A.M.; Rose, S.; Tochka, Z.L.; Tzeng, S.Y.; Norman, J.J.; Anselmo, A.C.; et al. Fabrication of fillable microparticles and other complex 3D microstructures. Science 2017, 357, 1138-1142. [CrossRef]

149. Lee, T.Y.; Ku, M.; Kim, B.; Lee, S.; Yang, J.; Kim, S.H. Microfluidic Production of Biodegradable Microcapsules for Sustained Release of Hydrophilic Actives. Small 2017, 13, 1700646. [CrossRef] [PubMed]

150. Lee, M.H.; Hribar, K.C.; Brugarolas, T.; Kamat, N.P.; Burdick, J.A.; Lee, D. Harnessing Interfacial Phenomena to Program the Release Properties of Hollow Microcapsules. Adv. Funct. Mater. 2012, 22, 131-138. [CrossRef]

151. Montazeri, L.; Bonakdar, S.; Taghipour, M.; Renaud, P.; Baharvand, H. Modification of PDMS to fabricate PLGA microparticles by a double emulsion method in a single microfluidic device. Lab Chip 2016, 16, 2596-2600. [CrossRef]

152. Seo, M.; Paquet, C.; Nie, Z.; Xu, S.; Kumacheva, E. Microfluidic consecutive flow-focusing droplet generators. Soft Matter 2007, 3, 986-992. [CrossRef]

153. Keohane, K.; Brennan, D.; Galvin, P.; Griffin, B.T. Silicon microfluidic flow focusing devices for the production of size-controlled PLGA based drug loaded microparticles. Int. J. Pharm. 2014, 467, 60-69. [CrossRef] [PubMed]

154. Xu, Q.; Hashimoto, M.; Dang, T.T.; Hoare, T.; Kohane, D.S.; Whitesides, G.M.; Langer, R.; Anderson, D.G.; David, H. Preparation of monodisperse biodegradable polymer microparticles using a microfluidic flow-focusing device for controlled drug delivery. Small 2009, 5, 1575-1581. [CrossRef]

155. Pessi, J.; Santos, H.A.; Miroshnyk, I.; Joukoyliruusi; Weitz, D.A.; Mirza, S. Microfluidics-assisted engineering of polymeric microcapsules with high encapsulation efficiency for protein drug delivery. Int. J. Pharm. 2014, 472, 82-87. [CrossRef]

156. Loizou, K.; Wong, V.-L.; Hewakandamby, B. Examining the Effect of Flow Rate Ratio on Droplet Generation and Regime Transition in a Microfluidic T-Junction at Constant Capillary Numbers. Inventions 2018, 3, 54. [CrossRef]

157. Bardin, D.; Kendall, M.R.; Dayton, P.A.; Lee, A.P. Parallel generation of uniform fine droplets at hundreds of kilohertz in a flow-focusing module. Biomicrofluidics 2013, 7, 034112. [CrossRef] [PubMed]

158. Yadavali, S.; Jeong, H.H.; Lee, D.; Issadore, D. Silicon and glass very large scale microfluidic droplet integration for terascale generation of polymer microparticles. Nat. Commun. 2018, 9, 1-9. [CrossRef] [PubMed]

159. Munira, S.L.; Hendriks, J.T.; Atmosukarto, I.I.; Friede, M.H.; Carter, L.M.; Butler, J.R.G.; Clements, A.C.A. A cost analysis of producing vaccines in developing countries. Vaccine 2019, 37, 1245-1251. [CrossRef] [PubMed]

(C) 2020 by the authors. Licensee MDPI, Basel, Switzerland. This article is an open access article distributed under the terms and conditions of the Creative Commons Attribution (CC BY) license (http://creativecommons.org/licenses/by/4.0/). 